\title{
Geomorphological Maps of Alluvial Plains and their Utilization for Mitigation of Natural Hazards: Flooding and Soil Liquefaction
}

\author{
Masahiko OyA \\ Nihon Kensetsu Consultant Inc., Higashi Gotannda, Shinagawa, Tokyo 141, Japan \\ (Emeritus professor, Waseda University)
}

\begin{abstract}
After World War II Japan faced the simultaneous problems of food shortages and flood hazards. To resolve these problems, agricultural and civil engineers were requested to obtain information on alluvial plains which provide land for major food production in the Japanese Islands.

Fortunately, Japanese geographers had already begun to study the alluvial plains as depositional geomorphology, greatly aided by the availability of aerial photographs. These circumstances gave birth to the Geomorphological Survey Map Showing Classification of Flood Stricken Areas.

The maps enable us to estimate the features of flooding not only of the past but also of the future. The reason why such a survey map serves the purpose of defining the type of flood is that the irregular surface of the plain, however slight, as well as the sandy and gravelly deposits, were formed by repeated floods. Consequently, the micro-topography of the plain, i.e., fans, natural levees, deltas, etc. tell the history of past floods. From this point of view, the author compiled the first "Topographical Survey Map of the Kiso River Basin (Nobi Plain) Showing Classification of Flood Stricken Areas" in 1956.

The accuracy of the map was actually confirmed by the high tide caused by the Typhoon Ise-Bay in 1959, i.e., three years after the preparation of the map. The results of the flood were almost the same as those predicted by the map. It is especially noteworthy that the area of invasion of flooding, caused by the high tide, coincides exactly with the delta area. This close relationship between high tide and geomorphology is manifested in many other cases, for example, in the routes of high tides and features of flooding in each geomorphological unit.

Utilizing the combination of geomorphological units, the flood type is classified into the following three types: overflow type, concentration type, and a combination type. An example of the overflow type is seen in the lower reaches of the Kiso River and Han River, the concentration type in the Chikugo River, and the combination type in the Vientiane Plain along the Mekong River.

The map is useful for estimating not only flooding but also soil liquefaction sites caused by earthquakes, and for the selection of bridge sites.
\end{abstract}

Key words: Geomorphological survey map, Flood, Alluvial plain, Soil liquefaction

\section{Geomorphological Survey Maps Showing Classification of Flood Stricken Areas in the Alluvial Plain}

\section{History of geomorphological survey maps showing classification of flood stricken areas}

After the Second World War, Japan faced simultaneous problems of food shortages and flood hazards. The staple food was rice, grown mainly in the alluvial plains which were devas- tated by frequent floods caused by typhoons and other heavy rains. In order to increase rice production, the Japanese needed to improve the rice fields in the alluvial plains. The Archipelago was devastated by large scale typhoons in 1945 (Typhoon Makurazaki), 1947 (Typhoon Catherine), 1948 (Typhoon Ion), 1950, 1951, 1953 and 1954. The devastation was especially extensive from Typhoon Catherine, when the embankment of the Tone River collapsed, and the main part of the Kanto Plain and the city of 
Tokyo were inundated. Maximum flood discharge at that time was $15,000 \mathrm{~m}^{3} / \mathrm{sec}$. at Yattajima, $14,500 \mathrm{~m}^{3} / \mathrm{sec}$. at Kawamata and 13,000 $\mathrm{m}^{3} / \mathrm{sec}$. at Kurihashi along the Tone River which has largest catchment area in Japan. According to the records of flood discharge at the lower part of the Tone River kept since the Meiji Restoration, the maximum flood discharge amount has been increasing gradually even though there has been little change in the amount of precipitation in the upper reaches of the river. Aki (1952) and some civil engineers believe that this phenomenon is due in part to river conservation works, for example a shortcut in a meandering course, and in part to the change of land use. Therefore, many civil engineers require integrated knowledge of the river basin for flood control (Oya 1972).

Directly after the typhoon, the Geographical Survey Institute, Ministry of Home Affairs (1947), researched the flooding and made a map showing the area of inundation, periods of submergence, depth of submergence, flood isochronal lines, and direction of flood current.

Widespread breaches of embankment occurred at the right bank of the Tone River which is located in the upper $4 \mathrm{~km}$ of Kurihashi; the water then flowed into the extinct river course which used to be the main Tone River in the Edo Period, and stagnated each back-marsh. Flooding was controlled by each natural levee along the extinct river courses, and the flowdown the Old Tone River Basin devastated paddies in the back-marsh and upland crop fields in the natural levee (Oya and Haruyama 1987).

According to the research, the relationship between the micro-topography of the plain and features of inundation becomes clear. The research had an influence on the birth of Geomorphological Survey Maps Showing Classification of Flood Stricken Areas.

On the other hand, the problem of food shortage was very severe. The Ministry of Agriculture wanted to increase the production of chemical fertilizer. Unfortunately, almost all the factories of chemical fertilizer were destroyed by bombing during the war because they were being used temporarily to manufacture gun powder.

There was also an idea to improve the breed- ing of rice plants, but it was impractical because the time needed to carry out the plan would have been too long. Therefore, only the improvement of land remained as a feasible measure. As a result, agricultural civil engineers required geomorphological knowledge of alluvial plains.

Fortunately, the time had already come for the study of alluvial plains among Japanese geographers. Before the war, topographic study was strongly influenced by studies in Europe and in the United States. Almost all the studies had been done in mountainous regions formed by erosion, as in Europe and the United States. Furthermore, considerable parts of the plains in Europe and North America were formed by glacial processes. In contrast, the alluvial plains in Japan were formed by deposition by fluvial action. Tada and his study group, including the author, wanted to begin research on the topography of depositional areas.

Directly after the Second World War, the Resources Council was established by the government of Japan following the recommendation of Dr. Ackerman who was a geographer in the General Headquarters (GHQ). The Resources Council was a good place for discussions among civil engineers, agricultural engineers and geographers.

"A Topographical Survey Map of the Kiso River Basin Showing Classification of Flood Stricken Areas", which was the first geomorphological survey map showing classification of flood stricken areas, was born under these circumstances.

\section{What is "a geomorphological survey map of a river basin showing classification of flood stricken areas"?}

A geomorphological survey map of a river basin enables us to estimate the nature and extent of an area submerged, the length of time an area would be under water, the depth of the standing water, the direction of flood currents, changes in the river course, the possibility of erosion and deposition, and numerous other details.

The reason why such a survey map helps to indicate flood types is that the relief features of a plain and its sandy and gravelly deposits have been formed by repeated floods. Consequently, 
the micro-topography of the plain and its sand and gravel accumulation preserve traces of past floods very well.

Geomorphological features, such as terraces, valley plains, fans, natural levees, back-marshes, deltas, etc., influence the extent and the nature of the flood. For example, on the alluvial fan, erosion and deposition of sand and gravel are common. Changes in the river channel are frequent; flood water drains off quickly and deposits consisting mostly of sand and gravel are left on the fan. The depth of the stagnant water is shallow, and sand deposited on the levees by flood water drains off well. In back-marshes, however, the water is generally deep and remains stationary for a long time, leaving a mantle of silt and clay. In a delta, the depth of water is shallower than that of a back-marsh area, but delta areas are sometimes subjected to high tides caused by typhoons and "tsunamis" (tidal waves) resulting from earthquakes (Tada and Oya 1959).

This shows clearly that by classifying the geomorphological configuration of an area subjected to frequent flooding, one can determine the nature of previous floods as well as the probable nature of future floods. From this point of view, the author has prepared geomor- phological survey maps showing classification of flood stricken areas of the main rivers in Japan and S. E. Asia.

These maps include those of the Kiso River and the Chikugo River in Japan, and those of the Mekong River on the Indo-China Peninsula, the Brahmaputra-Jamuna River in Bangladesh, Padang City in West Sumatra, and the Central Plain of Thailand. These maps were requested by the Resources Bureau of the Science and Technology Agency, the Ministry of Construction, the Economic Commission of Asia and the Far East (ECAFE), the Economic Commission of Asia and the Pacific (ESCAP), the Japan International Cooperation Agency (JICA) and the National Research Center for Disaster Prevention (Table 1).

\section{Method of preparing a geomorphological survey map of a river basin showing classific- ation of flood stricken areas in the alluvial plain}

In the preparation of a map, the target area is first classified by major geomorphological units such as mountains, terraces and lowlands. Secondly, the mountains are classified by altitude, structure, form and so forth. We classify the terraces into lava plateaus, upper, middle, and

Table 1 Geomorphological survey maps showing classification of flood stricken areas

\begin{tabular}{|c|c|c|c|c|}
\hline $\begin{array}{c}\text { Area or River } \\
\text { Name }\end{array}$ & $\begin{array}{c}\text { Published } \\
\text { Year }\end{array}$ & Name of the Map & Author & Publishing Office \\
\hline $\begin{array}{l}\text { Kiso River } \\
\text { (Nobi Plain) }\end{array}$ & 1956 & $\begin{array}{l}\text { Reconnaissance Topographical Survey } \\
\text { Map of the Lower Part of the Kiso } \\
\text { River Basin }\end{array}$ & M. OYA & Resources Council \\
\hline Chikugo River & 1957 & $\begin{array}{l}\text { Topographical Survey Map of the } \\
\text { Chikugo River Basin Showing } \\
\text { Classification of Flood Stricken Areas }\end{array}$ & M. OYA & $\begin{array}{l}\text { Resources Bureau, Science } \\
\text { and Technology Agency }\end{array}$ \\
\hline Isahaya & 1959 & $\begin{array}{l}\text { Topographical Survey Map of the City } \\
\text { of Isahaya and its Vicinity Showing } \\
\text { Classification of Flood Stricken Areas }\end{array}$ & M. OYA & $\begin{array}{l}\text { Resources Bureau, Science } \\
\text { and Technology Agency. }\end{array}$ \\
\hline Ishikari River & 1961 & $\begin{array}{l}\text { Topographical Survey Map of the } \\
\text { Ishikari River Showing Classification } \\
\text { of Flood Stricken Areas }\end{array}$ & M. OYA & $\begin{array}{l}\text { Resources Bureau, Science } \\
\text { and Technology Agency }\end{array}$ \\
\hline Yoshino River & 1963 & $\begin{array}{l}\text { Geomorphological Survey Map of the } \\
\text { Yoshino River Basin Showing } \\
\text { Classification of Flood Stricken Areas }\end{array}$ & M. Oya & $\begin{array}{l}\text { Resources Bureau, Science } \\
\text { and Technology Agency }\end{array}$ \\
\hline Kano River & 1966 & $\begin{array}{l}\text { Geomorphological Survey Map of the } \\
\text { Kano River Basin Showing } \\
\text { Classification of Flood Stricken Areas }\end{array}$ & M. OYA & $\begin{array}{l}\text { Resources Bureau, Science } \\
\text { and Technology Agency }\end{array}$ \\
\hline Kuzuryu River & 1968 & $\begin{array}{l}\text { Geomorphological Survey Map of the } \\
\text { Kuzuryu River Basin Indicating Areas } \\
\text { Subject to Flooding }\end{array}$ & M. OYA & $\begin{array}{l}\text { Resources Bureau, Science } \\
\text { and Technology Agency }\end{array}$ \\
\hline
\end{tabular}




\begin{tabular}{|c|c|c|c|c|}
\hline $\begin{array}{l}\text { Area or River } \\
\text { Name }\end{array}$ & $\begin{array}{c}\text { Published } \\
\text { Year }\end{array}$ & Name of the Map & Author & Publishing Office \\
\hline Sanriku Coast & 1961 & $\begin{array}{l}\text { Topographical Survey Map of the } \\
\text { Kesenuma and its Vicinity Showing } \\
\text { Classification of Tsunami Stricken Areas } \\
\text { Map Showing Classification of Micro- } \\
\text { topography of Shizugawa and its } \\
\text { Vicinity } \\
\text { Map Showing Classification of Topo- } \\
\text { graphy Shiogama Harborandits Vicinity } \\
\text { Showing Tsunami-Types of the Region }\end{array}$ & $\begin{array}{l}\text { T. NAKANO } \\
\text { M. IKEDA } \\
\text { K. } \\
\text { YAMAGUCHI } \\
\text { M. OYA } \\
\text { Y. } \\
\text { MATSUYAMA } \\
\text { K. KIKUCHI }\end{array}$ & $\begin{array}{l}\text { Coast Section, River Bureau } \\
\text { Ministry of Construction } \\
\text { Geographical Survey } \\
\text { Institute, Ministry of } \\
\text { Construction }\end{array}$ \\
\hline Ariake Coast & 1963 & $\begin{array}{l}\text { Topographical Survey Map of the } \\
\text { Ariake-Kai Basin (Kyushu) Showing } \\
\text { Classification of Flood Stricken Areas }\end{array}$ & $\begin{array}{l}\text { M. TAKASAKI } \\
\text { M. OYA } \\
\text { M. NAGASE } \\
\text { K. KIKUCHI }\end{array}$ & $\begin{array}{l}\text { Geographical Survey } \\
\text { Institute, Ministry of } \\
\text { Construction }\end{array}$ \\
\hline $\begin{array}{l}\text { Neyagawa River } \\
\text { (Osaka Plain) }\end{array}$ & 1972 & $\begin{array}{l}\text { Geomorphological Land Classification } \\
\text { Map of the Neyagawa River Basin } \\
\text { (Osaka and the Surrounding Area) } \\
\text { Indicating Areas Subject to Flooding }\end{array}$ & M. OYA & $\begin{array}{l}\text { National Research Center } \\
\text { for Disaster Prevention } \\
\text { Science }\end{array}$ \\
\hline Tsugaru Plain & 1977 & $\begin{array}{l}\text { Geomorphological Survey Map of the } \\
\text { Tsugaru Plain Indicating Areas } \\
\text { Subject to Flooding }\end{array}$ & $\begin{array}{l}\text { F. TADA } \\
\text { M. OYA } \\
\text { M. UMITSU } \\
\text { S. ARAI } \\
\text { K. WATANABE }\end{array}$ & Ministry of Education \\
\hline Shizuoka Plain & 1977 & $\begin{array}{l}\text { Geomorphological Survey Map of the } \\
\text { Shimizu-Shizuoka City } \text { Showing } \\
\text { Classification of Flood Stricken Areas }\end{array}$ & M. Oy A & $\begin{array}{l}\text { Civil Engineering Research } \\
\text { Institute, Ministry of } \\
\text { Construction }\end{array}$ \\
\hline Yahagi River & 1977 & $\begin{array}{l}\text { Geomorphological Survey Map of the } \\
\text { Yahagi River Plain Indicating Areas } \\
\text { Subject to Flooding }\end{array}$ & $\begin{array}{l}\text { M. Oya } \\
\text { S. SugIURA }\end{array}$ & $\begin{array}{l}\text { River Work Office at } \\
\text { Toyohashi, Ministry of } \\
\text { Construction }\end{array}$ \\
\hline Toyogawa River & 1978 & $\begin{array}{l}\text { Geomorphological Survey Map of the } \\
\text { Toyogawa River Basin Showing } \\
\text { Classification of Flood Stricken Areas } \\
\text { for Flood Control }\end{array}$ & $\begin{array}{l}\text { M. OYA } \\
\text { F. OMORI }\end{array}$ & $\begin{array}{l}\text { Work Office at Toyohashi, } \\
\text { Ministry of Construction }\end{array}$ \\
\hline Shonai River & 1979 & $\begin{array}{l}\text { Geomorphological Survey Map of the } \\
\text { Shonai River Basin Showing Classifica- } \\
\text { tion of Flood Stricken Areas for Flood } \\
\text { Control }\end{array}$ & $\begin{array}{l}\text { M. Oya } \\
\text { S. Sugiura }\end{array}$ & $\begin{array}{l}\text { Work Office at Shonai R., } \\
\text { Ministry of Construction }\end{array}$ \\
\hline Ogawara Lake & 1982 & $\begin{array}{l}\text { Geomorphological Land Classification } \\
\text { Map of the Lake Ogawara and its } \\
\text { Vicinity }\end{array}$ & $\begin{array}{l}\text { M. OYa } \\
\text { S. SUGIURA } \\
\text { Y. HiraI }\end{array}$ & $\begin{array}{l}\text { Takase River Comprehen- } \\
\text { sive Development Work } \\
\text { Office, Ministry of Construction }\end{array}$ \\
\hline Shonai Plain & 1982 & $\begin{array}{l}\text { Geomorphological Land Classification } \\
\text { Map of the Shonai Plain Illustrating } \\
\text { Features of Flooding and Soil Lique- } \\
\text { faction }\end{array}$ & $\begin{array}{l}\text { M. OYa } \\
\text { K. KOTODA } \\
\text { K. WAKAMATSU } \\
\text { S. KuBO }\end{array}$ & $\begin{array}{l}\text { Work office at Sakata, } \\
\text { Ministry of Construction }\end{array}$ \\
\hline Abashiri River & 1984 & $\begin{array}{l}\text { Geomorphological Survey Map of the } \\
\text { Abashiri River Basin Showing } \\
\text { Classification of Flood Stricken Areas }\end{array}$ & $\begin{array}{l}\text { M. OYa } \\
\text { M. UMITSU } \\
\text { S. HARUYAMA } \\
\text { Y. HIRAI }\end{array}$ & $\begin{array}{l}\text { Division of Development } \\
\text { and Construction at } \\
\text { Abashiri Bureau of } \\
\text { Hokkaido Development }\end{array}$ \\
\hline Agano River & 1984 & $\begin{array}{l}\text { Geomorphological Survey Map of the } \\
\text { Agano River Basin Showing Clas- } \\
\text { sification of Flood Stricken Area }\end{array}$ & $\begin{array}{l}\text { M. OYa } \\
\text { Y. Kato }\end{array}$ & $\begin{array}{l}\text { River Work Office at } \\
\text { Aganogawa, Ministry of } \\
\text { Construction }\end{array}$ \\
\hline Tokoro River & 1985 & $\begin{array}{l}\text { Geomorphological Survey Map of the } \\
\text { Tokoro River Basin Showing Clas- } \\
\text { sification of Flood Stricken Area }\end{array}$ & $\begin{array}{l}\text { M. OYa } \\
\text { M. UMITSU } \\
\text { S. HARUYAMA } \\
\text { Y. HIRAI }\end{array}$ & $\begin{array}{l}\text { Division of Development } \\
\text { and Construction at } \\
\text { Abashiri Bureau of } \\
\text { Hokkaido Development }\end{array}$ \\
\hline Kise River & 1985 & $\begin{array}{l}\text { Geomorphological Land Classification } \\
\text { Map of the Kise River Basin Located } \\
\text { near Mt. Fuji }\end{array}$ & $\begin{array}{l}\text { M. OYA } \\
\text { K. KoTODA } \\
\text { K. WAKAMATSU } \\
\text { Y. TAKAGI } \\
\text { A. MATSUBARA } \\
\text { S. IIDA }\end{array}$ & $\begin{array}{l}\text { Work office of Numazu, } \\
\text { Ministry of Construction }\end{array}$ \\
\hline
\end{tabular}




\begin{tabular}{|c|c|c|c|c|}
\hline $\begin{array}{c}\text { Area or River } \\
\text { Name }\end{array}$ & $\begin{array}{c}\text { Published } \\
\text { Year }\end{array}$ & Name of the Map & Author & Publishing Office \\
\hline $\begin{array}{l}\text { Kasumigaura } \\
\text { Lake } \\
\text { Kitaura Lake }\end{array}$ & 1986 & $\begin{array}{l}\text { Geomorphological Land Classification } \\
\text { Map of the Lake Kasumigaura, Kitaura } \\
\text { and its Vicinity }\end{array}$ & $\begin{array}{l}\text { M. OYa } \\
\text { Y. Kato } \\
\text { S. HARUyama } \\
\text { Y. HiRAI } \\
\text { K. KOBA YASHI } \\
\text { Y. INOUE } \\
\text { S. OSHIZAWA }\end{array}$ & $\begin{array}{l}\text { Work office of } \\
\text { Kasumigaura, Ministry of } \\
\text { Construction }\end{array}$ \\
\hline $\begin{array}{l}\text { Katsushika } \\
\text { Ward }\end{array}$ & 1985 & $\begin{array}{l}\text { Geomorphologic Land Classification } \\
\text { Map of the Katsushika Ward (Tokyo) } \\
\text { and its Vicinity }\end{array}$ & $\begin{array}{l}\text { M. Oya } \\
\text { S. HARUYAMA }\end{array}$ & $\begin{array}{l}\text { Board of Education of } \\
\text { Katushika Ward }\end{array}$ \\
\hline Sagami Bay & 1991 & $\begin{array}{l}\text { Geomorphological Land Classification } \\
\text { Map Northern Coast of the Sagami } \\
\text { Bay }\end{array}$ & $\begin{array}{l}\text { M. Oya } \\
\text { A. MatSUbara } \\
\text { S. Kubo } \\
\text { K. KODERA }\end{array}$ & $\begin{array}{l}\text { Keihin Work office, } \\
\text { Ministry of Construction }\end{array}$ \\
\hline Yodo River & 1993 & $\begin{array}{l}\text { Geomorphological Survey Map of the } \\
\text { Yodo River Showing Classification of } \\
\text { Flood Stricken Area }\end{array}$ & $\begin{array}{l}\text { M. Oy A } \\
\text { S. KuBo }\end{array}$ & $\begin{array}{l}\text { Yodo River Work office, } \\
\text { Ministry of Construction }\end{array}$ \\
\hline Naruto Straits & 1994 & $\begin{array}{l}\text { Geomorphologic Map of the Coast and } \\
\text { Sea Bottom of the Tokushima } \\
\text { Prefecture (River Mouth of the } \\
\text { Yoshino and Straits of Naruto) }\end{array}$ & $\begin{array}{l}\text { M. Oya } \\
\text { S. HARUy AMA }\end{array}$ & Tokushima Prefecture \\
\hline $\begin{array}{l}\text { Nam Gum } \\
\text { (Thailand) }\end{array}$ & 1961 & $\begin{array}{l}\text { Topographical Survey Map of the Nam } \\
\text { Gum Showing the Classification of } \\
\text { Flood Stricken Area }\end{array}$ & M. OYA & $\begin{array}{l}\text { Mekong Reconnaissance } \\
\text { Team, Government of } \\
\text { Japan }\end{array}$ \\
\hline $\begin{array}{l}\text { Mekong River } \\
\text { Vientiane Plain } \\
\text { (Laos and } \\
\text { Thailand) }\end{array}$ & 1967 & $\begin{array}{l}\text { Geomorphological Survey Map of the } \\
\text { Mekong River Basin (Vientiane, Nong- } \\
\text { khai and the Surrounding Area situated } \\
\text { immediatelydownstreamfromPa Mong) } \\
\text { Indicating Areas Subject to Flooding }\end{array}$ & M. OYA & Mekong Committee \\
\hline $\begin{array}{l}\text { Brahmaputra- } \\
\text { Jamuna River } \\
\text { (Bangladesh) }\end{array}$ & 1976 & $\begin{array}{l}\text { Geomorphologic Map of the } \\
\text { Brahmaputra-Jamuna River Basin } \\
\text { (Sirajganj and its Surrounding Area) }\end{array}$ & M. OyA & JICA \\
\hline $\begin{array}{l}\text { Ganges Plain } \\
\text { (Bangladesh) }\end{array}$ & 1976 & $\begin{array}{l}\text { Geomorphologic Map of the R. Brah- } \\
\text { maputra-Jamuna and R. Ganges Plain }\end{array}$ & M. Oya & JICA \\
\hline $\begin{array}{l}\text { Padang Plain } \\
\text { (Sumatra, } \\
\text { Indonesia) }\end{array}$ & 1983 & $\begin{array}{l}\text { Geomorphological Survey Map of } \\
\text { Padang City and Surrounding Area in } \\
\text { Wést Sumatra Showing Classification } \\
\text { of Flood Striken Areas }\end{array}$ & M. OYA & JICA \\
\hline $\begin{array}{l}\text { Nile River } \\
\text { (Egypt) }\end{array}$ & 1986 & $\begin{array}{l}\text { Geomorphological Land Classification } \\
\text { Map of the Nile River Basin }\end{array}$ & $\begin{array}{l}\text { M. OYA } \\
\text { S. HARUYAMA }\end{array}$ & Waseda University \\
\hline $\begin{array}{l}\text { Mae Nam Chao } \\
\text { Phraya Central } \\
\text { Plain of } \\
\text { Thailand }\end{array}$ & 1989 & $\begin{array}{l}\text { Geomorphological Survey Map of the } \\
\text { Central Plain of Thailand Showing } \\
\text { Classification of Flood-inundated Areas }\end{array}$ & \begin{tabular}{l|} 
H. OKURA \\
S. HARUYAMA \\
M. OYA \\
S. VIBUSRESTH \\
R. SUWAN- \\
WERAKAMIORN
\end{tabular} & $\begin{array}{l}\text { National Research Center } \\
\text { for Disaster Prevention, } \\
\text { Japan, Waseda University } \\
\text { Remote Sensing Division, } \\
\text { National Research Council } \\
\text { of Thailand }\end{array}$ \\
\hline $\begin{array}{l}\text { Kraseio River } \\
\text { Western Part of } \\
\text { the Central Plain } \\
\text { of Thailand }\end{array}$ & 1991 & $\begin{array}{l}\text { Geomorphological Survey Map of the } \\
\text { Kraseio River Basin in the Western } \\
\text { Part of the Central Plain of Thailand } \\
\text { Showing Classification of Flood- } \\
\text { inundated Areas }\end{array}$ & \begin{tabular}{l|} 
H. OKURA \\
S. HARUYAMA \\
M. OYA \\
S. VIBUSRESTH \\
R. SUWAN- \\
WERAKAMIORN
\end{tabular} & $\begin{array}{l}\text { National Research Center } \\
\text { for Disaster Prevention, } \\
\text { Japan, Waseda University } \\
\text { Remote Sensing Division, } \\
\text { National Research Council } \\
\text { of Thailand }\end{array}$ \\
\hline
\end{tabular}

lower terraces; the lowlands into dissected fans, alluvial fans, natural levees, back-marshes and deltas. In addition, we include the classification of man-made topography, such as reclaimed land, and artificially filled fields, utilizing aerial photographs. The map, thus prepared, is then 
Table 2 Relationships between geomorphological units and state of flooding (including man made topography)

\begin{tabular}{|c|c|}
\hline Geomorphological elements & State of flooding \\
\hline Terrace & Never submerged at flood time. \\
\hline Valley Plain & $\begin{array}{l}\text { In flood time when submerged, velocity of the flood current is fast and water } \\
\text { drains off well. }\end{array}$ \\
\hline Fan & $\begin{array}{l}\text { In flood time, the erosion, deposition, change of water course are seen, when } \\
\text { submerged, the water drains off well. }\end{array}$ \\
\hline Natural levee & $\begin{array}{l}\text { This part gets submerged, in an extraordinary flood time, but the water drains } \\
\text { off well. }\end{array}$ \\
\hline Back-marsh & This part is long submerged with deep depth of water. \\
\hline Delta & $\begin{array}{l}\text { This area gets submerged the longest in flood time. } \\
\text { This area is attacked by high tide frequently. }\end{array}$ \\
\hline Former river course & The flood water runs through this channel in extraordinary flood time. \\
\hline Sand spits & $\begin{array}{l}\text { This part gets submerged, in an extraordinary flood time, but the water drains } \\
\text { off well. }\end{array}$ \\
\hline Sand dune & Never submerged at flood time. \\
\hline Lowland between sand dune & This part gets submerged at torrential rain fall. \\
\hline Reclaimed land & $\begin{array}{l}\text { This area gets submerged the longest in flood time. } \\
\text { This area is attacked by high tide frequently. }\end{array}$ \\
\hline $\begin{array}{l}\text { Artificially filled up field } \\
\text { in shallow sea }\end{array}$ & This area is attacked by high tide, or Tsunami, but the water drains off well \\
\hline
\end{tabular}

checked using information related not only to geomorphology but also to flooding. The relationships between geomorphology and features of flooding are shown in Table 2.

\section{Comparison between Japan and continental regions (Europe and North America) in terms of the geomorphology utilizing the geomor- phological land classification map}

The I.G.U. Commission on Geomorphological Survey and Mapping, which was formerly called the I.G.U. Commission on Applied Geomorphology from 1956 to 1968, completed the International Geomorphological Map of Europe (1/ 250,000 ) in 1976 . The commission was guided by J. Demek (C.S.S.R.), H. Th. Verstappen (The Netherlands), F. Joly and J. Tricart (France), J. F. Gellert (Germany), G. B. Castiglioni (Italy), C. Embleton (U.K.), M. Klimazewski (Poland), N. V. Bashenina (U.S.S.R.), and St. Onge (Canada). The legend of the map was compiled by J. Demek as the "Manual of Detailed Geomorphological Mapping” (1972).

In 1980 , the I.G.U. Working Group on Geomorphology of River and Coastal Plains was established. The Working Group was guided by J. A. M. ten Cate (The Netherlands), M. Oya
(Japan), G. B. Castiglioni (Italy), and J. Suzupriyczynski (Poland).

The purposes of the Working Group were a) the compilation of geomorphological maps of the flood areas in some important plains in the world, and b) making a country report on the geomorphology of plains related to natural and man made hazards (Oya 1990).

Through the result of the studies by the above mentioned Commission and Working Group, the author has recognized the following difference on geomorphology and mapping between the Continental Region especially in Europe and North America, and Japan.

(a) In Europe, the geomorphological classification has been done based on the agent; slope, composition, age of formation, formal coastal line were added to this classification. In Japan, the classification has been done based on the morphology, especially utilizing the breakpoints of geomorphological units.

(b) In Europe, the classification laid stress on climatic geomorphology and erosional geomorphology but in Japan, on depositional geomorphology.

(c) In Europe and North America the classification is based on glacier and glacial geomor- 


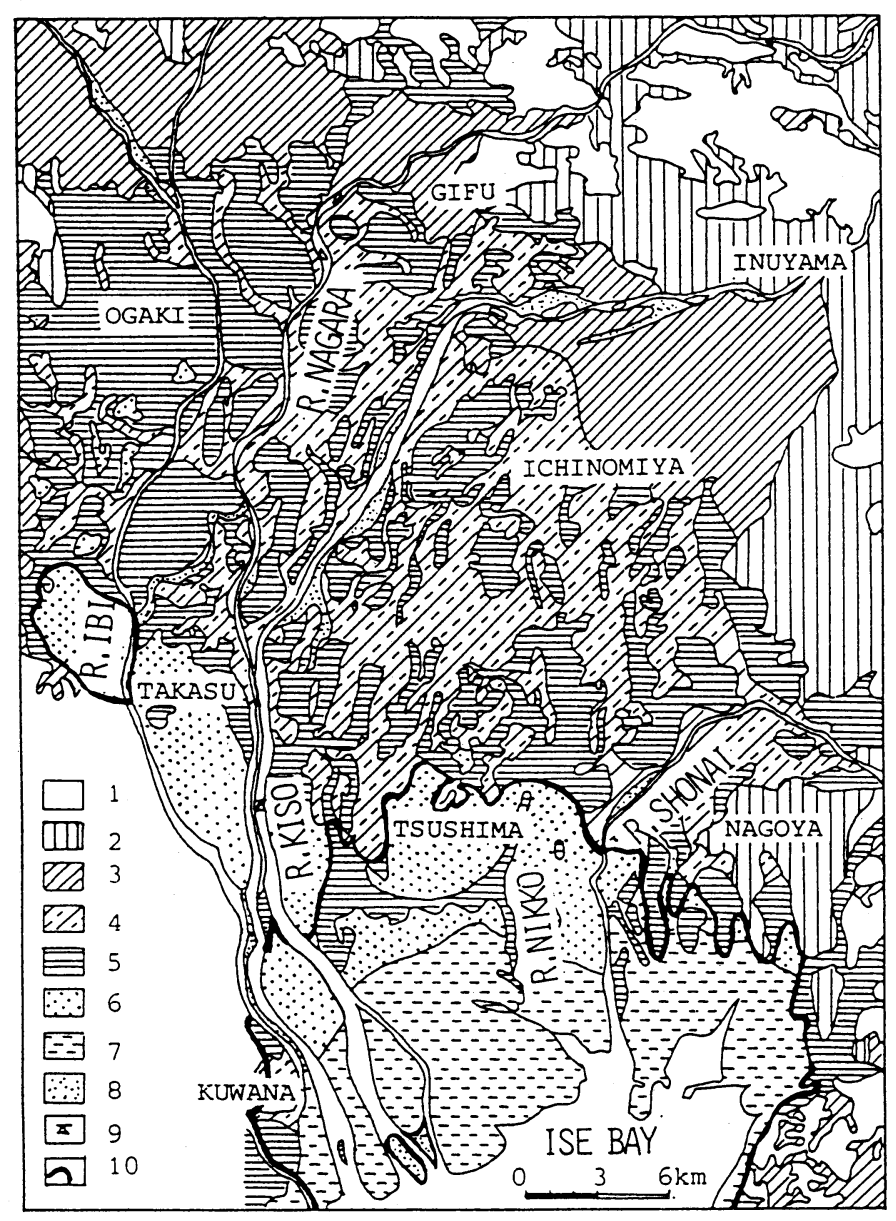

EXPLANATORY NOTES
1. Mountain
6. Delta
2. Terrace
7. Reclaimed Land
3. Fan
8. Dry River Bed
4. Natural Levee
9. Tidal Limit
5. Back-Swamp
10. Area Inundated in 1959

Figure 1. Topographical survey map of the Kiso River Basin (Nobi Plain) showing classification flood stricken areas (Oya 1956).

phology, with karstic regions being very detailed, but being very simple in Japan.

The Author estimate that the above mentioned differences on geomorphology resulted from the background, i.e., the main parts of Europe and North America belong to the epeirogenic zone with small precipitation, but Japan is located in the orogenic zone with typhoons.

Uchida (1976) applied the international geomorphological land classification of Europe to
Japan utilizing methods of the above mentioned "Manual of Detailed Geomorphological Mapping". She concluded that she couldn't use the legends of the International Land Classification directly and that she would be forced to add legends suitable for the Japanese situation in order to apply the standard of the International Land Classification made in epeirogenic movement areas to Japan's orogenic movement areas. 
Experiments Using Natural Flooding and Validation of a Geomorphological Survey Map of a River Basin Showing Classification of Flood Stricken Areas

High tides caused by the Typhoon Ise-Bay and a geomorphological survey map of the Nobi Plain located at the lower reaches of the Kiso River

The author prepared the map of A Topographical Survey Map of the Kiso River Basin Showing Classification of Flood Stricken Areas in 1956 (Fig. 1). The Nobi Plain in the lower reaches of the Kiso River consists of fans, natural levees with back-marshes, deltas, etc. There is a large fan, the apex of which is at the City of Inuyama. In addition, three or four distinct natural levees are also seen south of the fan. When a river bed is greatly raised, it causes the river channel to shift (Oya 1988).

In the Nobi Plain, several divergent natural levees, which were formed by repeated flooding, can be easily recognized. The line connecting the northern part of Nagoya City and Tsushima City to the south is a delta which was formed by fluvial action of rivers and by marine action. The southern-most part of the delta is land reclaimed after the 17 th century. Around Nagoya Port is an artificially filled field, which was built after the Meiji Restoration in 1867.

On September 26, 1959, the southern part of the plain where the city of Nagoya is located was attacked by a super scale typhoon, the Typhoon Ise-Bay. The high tide caused by the typhoon was reported to be as high as $3.89 \mathrm{~m}$ (12.8 feet) in Nagoya Port. As a result of the disaster, some 5,200 persons died and about 530 billion yen (about $\$ 1,472,000,000$ at that time) in properties were lost.

The map's utility was demonstrated by the typhoon in 1959. The results of the flood were almost the same as those predicted by the map. The close relationship between high tides and geomorphology was highly visible in many cases. It is especially noteworthy that the area

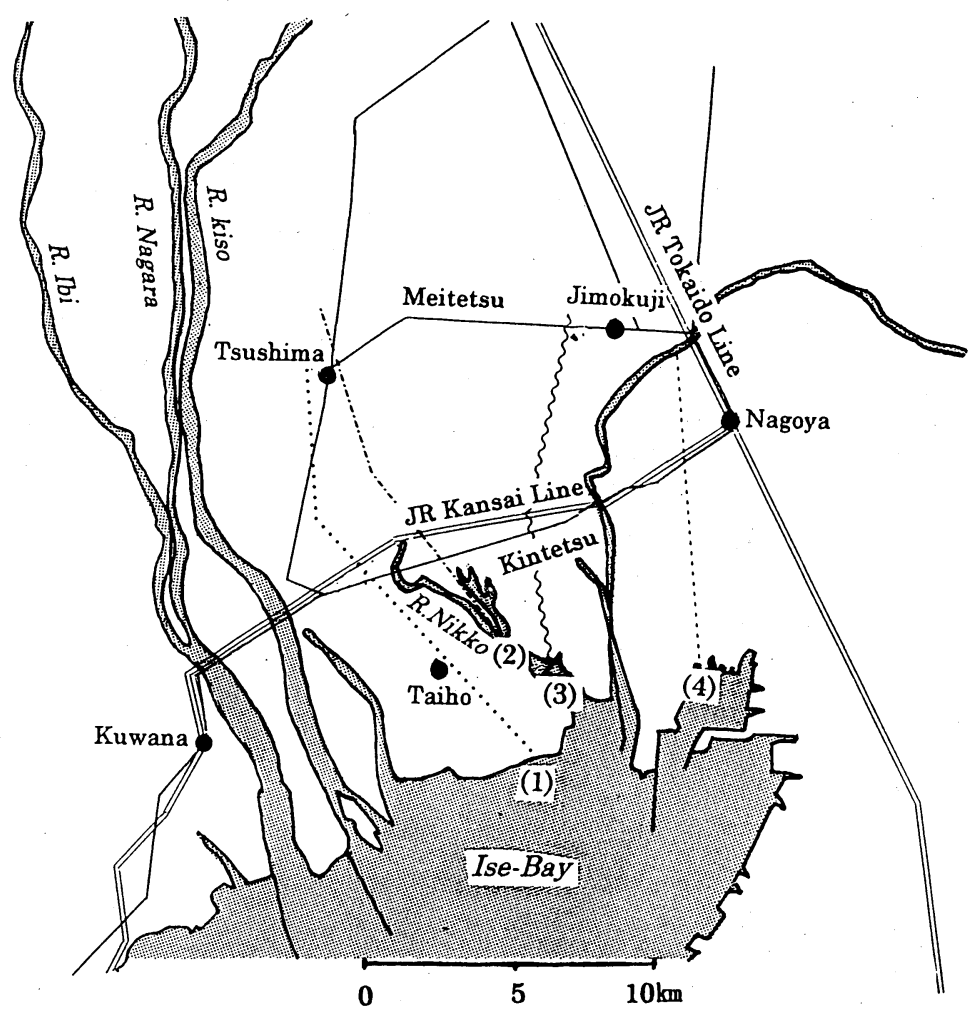

Figure 2.1. Location of the profile of high tide (Nakano and Oya 1960; modified). 

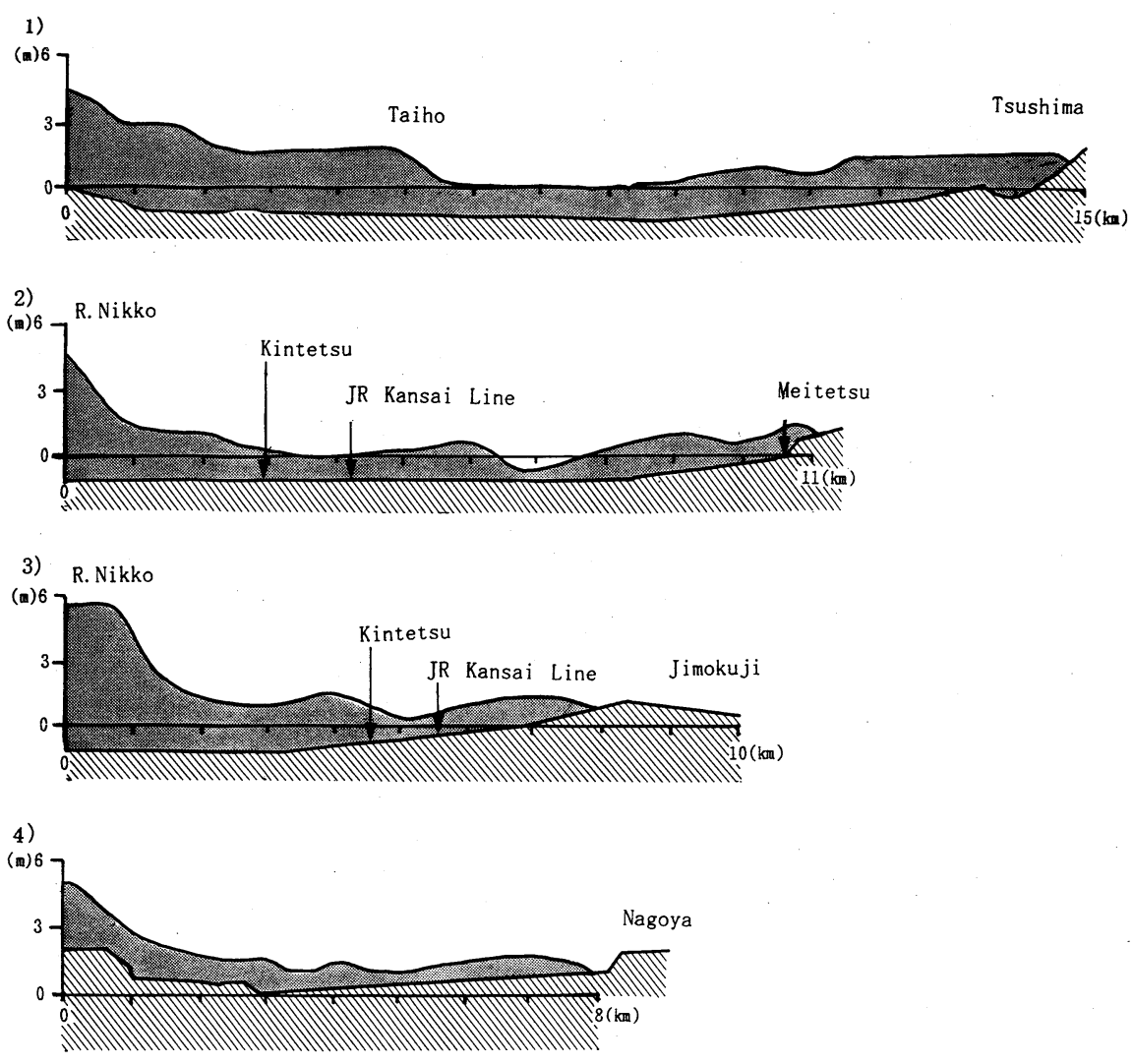

Figure 2.2. Features of the profile of high tide (Nakano and Oya 1960; modified).

of invasion of flooding, caused by the high tide, coincides exactly with the delta area.

(1) Features of the flooding

The flood type-the extremity of the high tide and that of the sea water, the depth of the stagnant water, its period of stagnation, the velocity of the current, the erosion, and deposits - vary remarkably according to the landforms. Here, factors such as fans, natural levees, backmarshes and the deltas have a decisive influence upon deciding the types of floods (Nakano et al. 1960).

(2) Limit of intrusion of high tide

The coast of Nagoya Port was hit by a high tide of 3.89 meters above sea level. The high tide intruded on the inland area with high velocity. But did not proceed very far, disappearing at about sea level. The line where the high tide disappeared was found at the boundary of reclaimed land, that is, the coastal line of the 16 th century. Beyond this line, the sea water seen at spring tide the next day was 1 meter above sea level. The extremity of the influx was seen at the boundary of the delta, that is, the coastal line from the latter prehistoric age to early historic age (Fig. 2).

(3) Invasion Routes of High Tide

The main routes of the high tide invasion are provided by landforms like rivers, channels, ancient waterways, etc.

Rivers: The three large rivers, the Kiso River, the Nagara River, the Ibi River, and other small rivers flow into Ise-Bay. These rivers made convenient routes for the high tide to proceed. The high tide proceeded as far as about $24 \mathrm{~km}$ from the mouth of the Kiso River. The velocity of the transmission of the highest water level of the tidal waves was very fast: from $5 \mathrm{~m} / \mathrm{sec}$. to $8 \mathrm{~m} / \mathrm{sec}$.

Channels: There are many channels in the city of Nagoya: Nakagawa Channel, Horikawa Channel, etc. These channels provided easy 
access for the high tides to proceed. However, there were gates in the mouth of the Nakagawa Channel, which prevented the high tides from intruding.

Ancient waterways: Ancient waterways are seen in the delta here and there. The ancient waterways were changed to paddy fields several hundred years before the high tide, but, nevertheless, the routes were very convenient for the intrusion of the high tide.

\section{Application to the Ariake-Sea Lowland: Esti- mation of the potential state of flooding caused by high tides}

The Ariake-Sea Lowland consists of fans, lower fans, upper deltas, deltas and reclaimed land. The Sagaego River, located east of Saga City, runs from west to east, i.e., parallel with the coastline. This is unlike most of the rivers in this area which flow from north to south. Many shell mounds are seen in the northern part but none in the southern part (Fig. 3).

The author has presumed that the line connecting Saga City and Sagaego River is a former coastline, around $3 \mathrm{~m}$, correlates with the line connecting the cities of Nagoya and Tsushima in the Nobi Plain.

We have experienced high tides several times in the Ariake Sea, Kyushu. For example, on September 14, 1959, a typhoon attacked the Ariake Sea which resulted in a high tide. Utilizing the record of high tide caused by the typhoon, the Ministry of Construction calculates the potential height of the high tide to be $7.5 \mathrm{~m}$.

Using the theory which was established in the Typhoon Ise-Bay in the Nobi Plain, the author estimated the inner limit of a high tide or the sea water and state of flooding in the area.

If we have a high tide with a height of $7.5 \mathrm{~m}$, the high tide and sea water which intrudes the inland area will be stopped at the $3 \mathrm{~m}$ line.

From this point of view, the Ariake-Sea Lowland can be divided as follows: (1) those areas which will be devastated by the high tide; (2) those areas which will be partly devastated by the high tide and sea water; and (3) those areas which will be slightly submerged by sea water.

\section{Relationships Between a Combination of the Geomorphological Units and Flood Types of the River Basin: Overflowing Type, Concentration Type and Combina- tion Type}

\section{Overflowing type: the Kiso River, Nobi Plain and Han River, Korea}

The Kiso River: The Kiso River flowing across the Nobi Plain has formed big alluvial fans, natural levees and deltas in its lower reaches. This triple combination of geomorphological units,

$$
\begin{gathered}
\text { Fan }+ \text { Natural Levee+Delta, } \\
\text { (Back-marsh) }
\end{gathered}
$$

indicates that the deposition by the main stream is remarkable.

A cross section of the Kiso River and its surrounding plain shows that the land becomes higher as one moves nearer to the river. That is why when a flood occurs the water spreads from the natural levee to the back-marsh or delta. There has been no severe flooding during the last 30 years, but due to the Typhoon IseBay, the high tide went upstream through the Kiso River, the Nagara River and the Ibi River breaking the embankment and overflowing from the main stream to the adjacent lowland (Oya 1973a, 1988).

There is a close relationship between the topographic features of the alluvial plain and the mountain. About 53.3\% of the drainage area of the Kiso River is above $700 \mathrm{~m}$. Similarly more than $52.2 \%$ of that drainage area is steeper than 30 degrees. The relief energy of the area is big, showing a maximum of $1,300 \mathrm{~m}$. The mountains were uplifted about $2,000 \mathrm{~m}$ i.e. $60-70 \%$ of the present height during the Quaternary Age. Uplift of the ground is continuing at a rate of 5$11 \mathrm{~cm}$ in the last 50-60 years. The principal rocks include granite, andesite, etc. which are weathered easily. These geomorphological features of the Kiso River Basin clearly demonstrate a large and continuous supply of sand and gravel in the region. Even the reservoirs for hydroelectric power stations at Yaotsu and Oi are facing a great problem of silting owing to the heavy influx of sand and gravel in the river. 

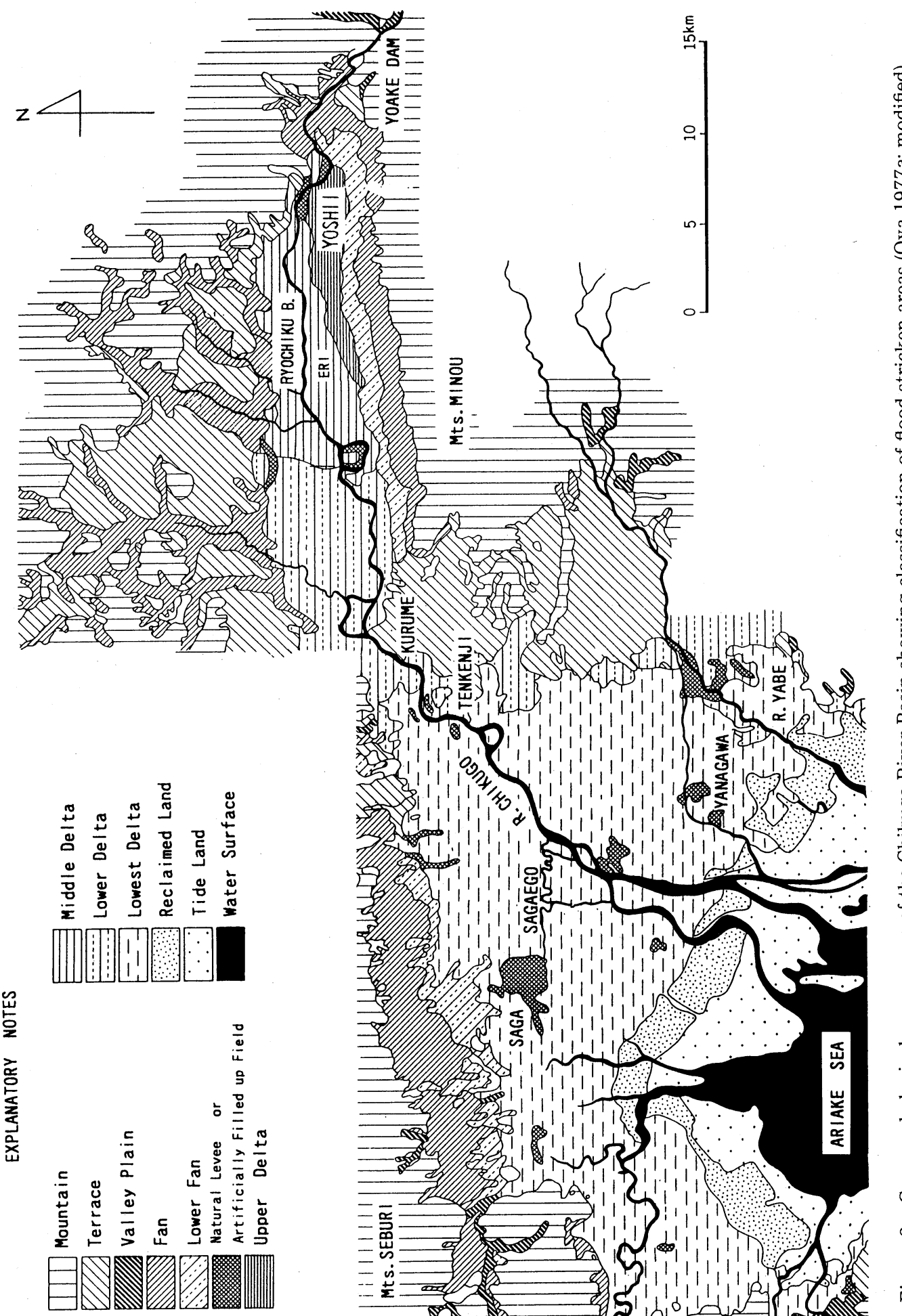

蕰
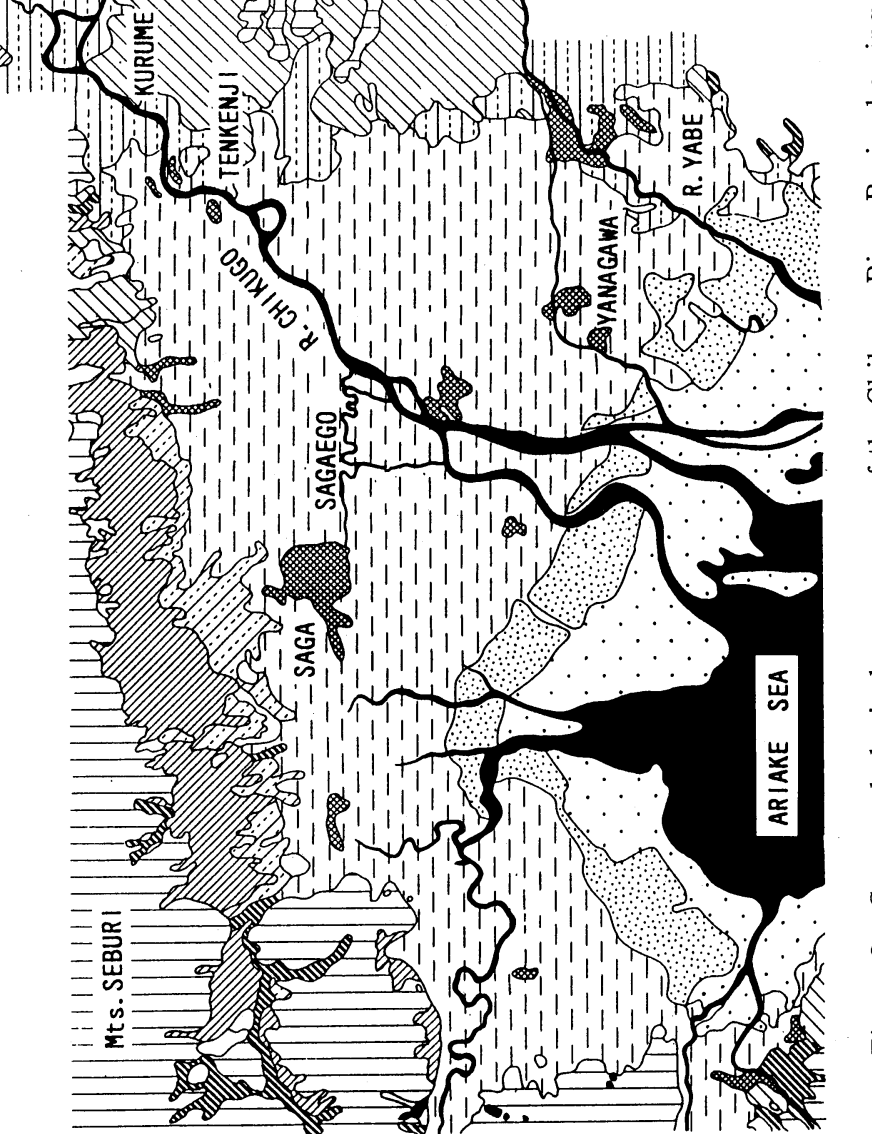

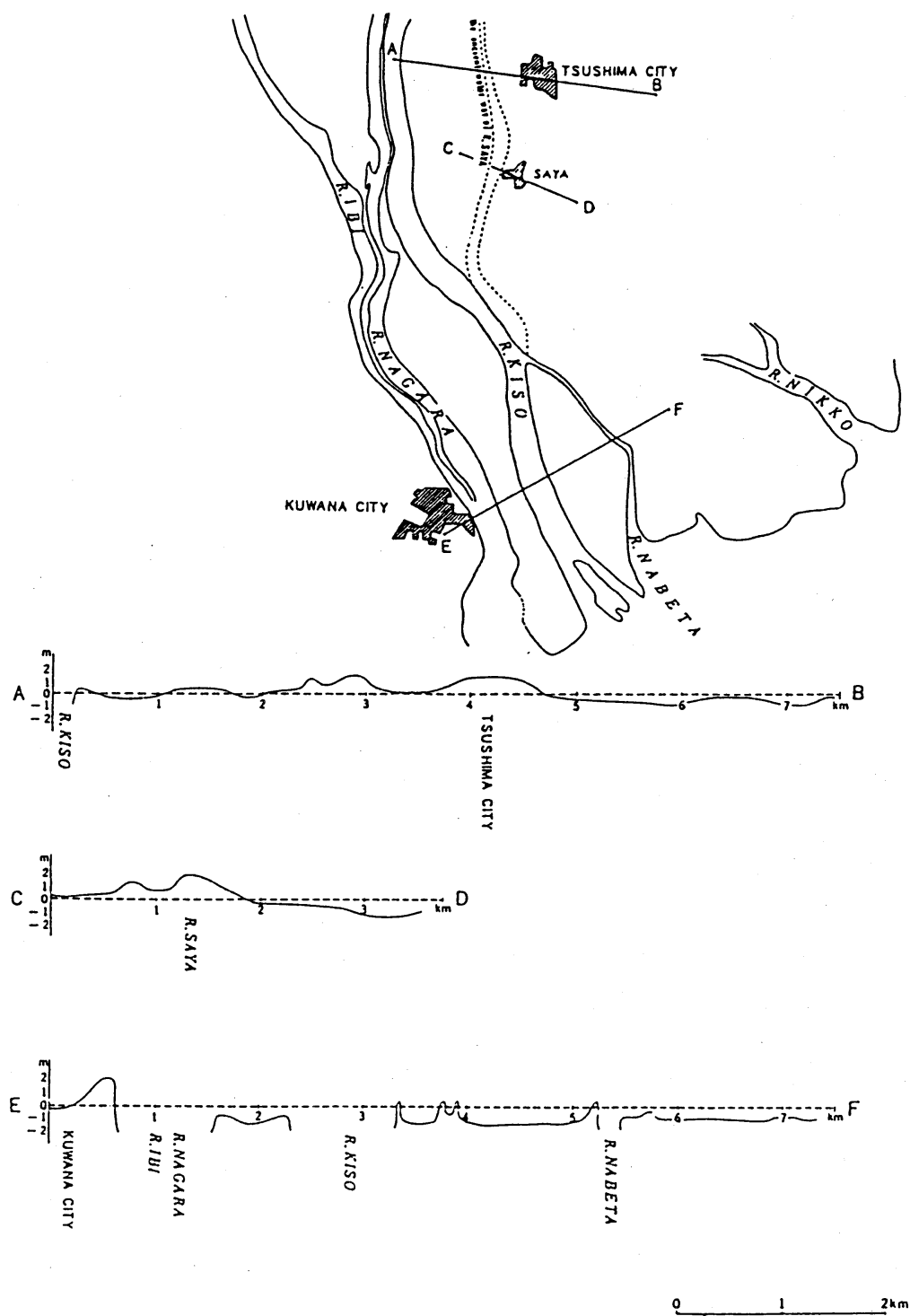

Figure 4. Topographical cross-section of the lower reaches of the Kiso River Basin (Oya 1973a).

Owing to these geomorphological and geological features of the basin, landslides occur during severe rainfalls and a large quantity of debris is deposited on the river bottom. The river runs along a continuous canyon and there is no intermontane depression along its course. Therefore, the sand and gravel which is deposited by landslides does not stop on the way but flows directly down to the plain.

A large alluvial fan, the apex of which is at the city of Inuyama, was formed. In addition, three or four natural levees are also seen from the fan margin to the south. When a river bed is greatly raised shifting of the river channel brings big floods forming a new natural levee along the channel. In the Nobi Plain, several divergent natural levees which were formed by this process can be easily recognized (Fig. 1).

Although the topography of the Nobi Plain is susceptible to flooding, it is beneficial in the utilization of the river for irrigation and as a water supply throughout the Nobi Plain (Fig. 4). 


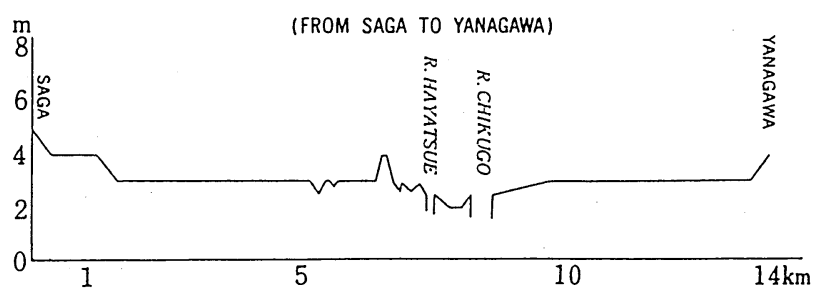

(FROM KANZAKI TO KOINUZUKA)
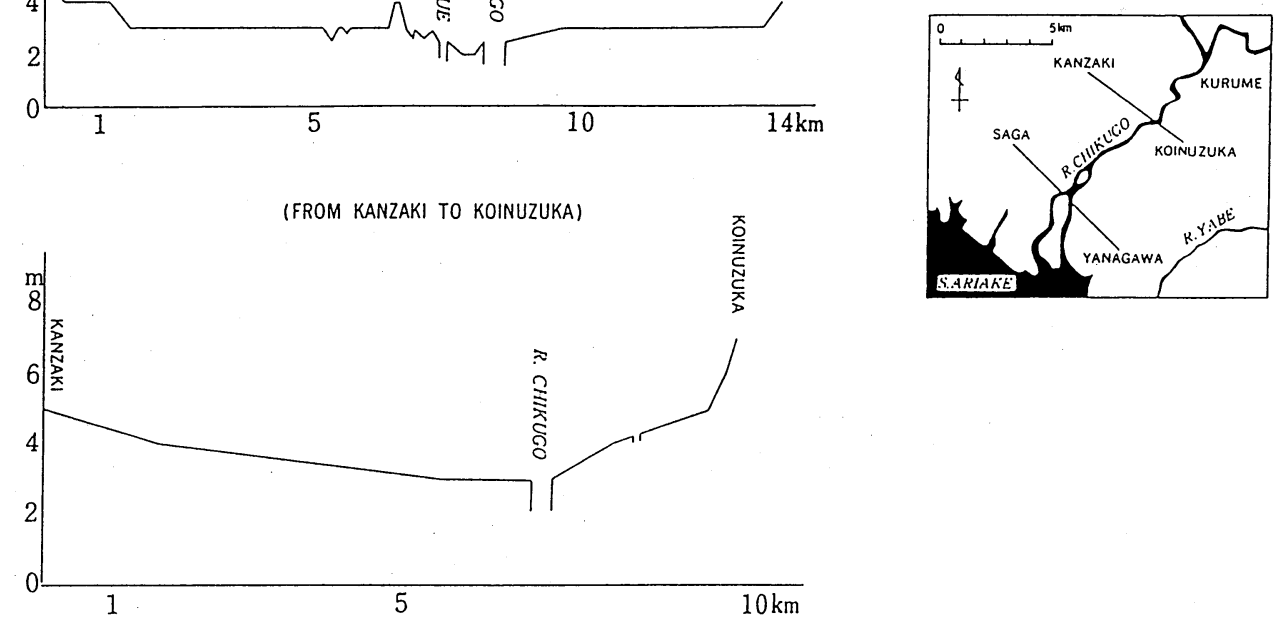

Figure 5. Topographical cross-section of the plain of the lower reaches of the Chikugo River Basin (Oya 1973a).

This kind of overflowing type is also seen in the Han River, Korea.

\section{Concentration (retarding) type: Chikugo River Plain}

The Chikugo River: The Chikugo river has large fans formed by the tributaries coming from north and south of the main stream, but has a tiny fan formed by the main river. Even the natural levees, which are seen in general along the lower course from the fan, are rarely seen here. The width of the middle and lower delta which is developed along the main course is narrow, about $7 \mathrm{~km}$. The combination of the geomorphological units is as follows (Fig. 3).

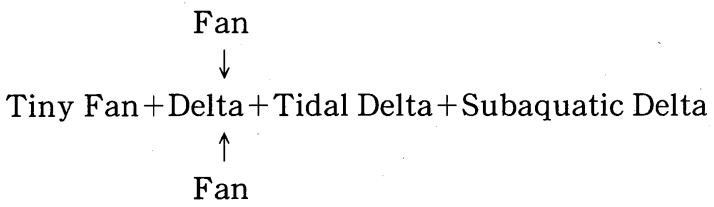

If we compare these geomorphological features with that of the Kiso River Basin, we can see distinct regional differences between the two basins. For example, the mountains in the Kiso Basin are higher than the Chikugo Basin. Similarly the slope of the Chikugo Basin, as might be expected, is smaller than that of the
Kiso. The maximum relief energy is a mere 800 $\mathrm{m}$ in the former, while it is $1,300 \mathrm{~m}$ in the latter. Hence, the Chikugo River Basin is less susceptible to landslides.

There are several intermontane depressions, such as, the Oguni and Hida depressions along the main stream and the Handa Plateau and Kusu Depression along the Kusu River which is a tributary of the Chikugo River. When a river has a depression, a considerable part of the larger gravel transported from the upper reaches is stopped in the depression preventing sand and small-size gravel from moving downward. Leveling from 1893 to 1963 shows that most of the upper part of the Kusu depression sunk $9.19 \mathrm{~cm}$ during the 70 years, while the canyon located in the lower reaches of the depression rose $9.2 \mathrm{~cm}$. This crustal movement is one of the causes of the stopping of the flow of sand and gravel to the lower reaches. A study of the silting of the reservoir of the Yoake Dam shows that the deposition rate is only $1 / 42$ of the Kiso River (Tada et al. 1957).

In the middle reaches of the Chikugo River, the closer to the river the land is, the lower it becomes (Fig. 5). This is mainly due to erosion and the ground dipping along the main stream, and maximum deposition by the tributaries 



Figure 6. A Geomorphological survey map of the Mekong River Basin indicating area subject to flooding (Oya 1967).

along the foot hill with decreasing tendency towards the main stream. Owing to this peculiar topography, the flood water flows down from the higher surrounding area into the main stream. In fact, when overflow occurs, the flood water does not disperse but flows into the main stream at the lower reaches. This type of flooding contrast was observed during the flood of
1953 when the left bank dikes were broken at Eri and flood water invaded the protected area breaking the left dike from the back side and rejoining the main river.

Due to the floods of 1921, 1935 and 1941, shortcuts were made at the meandering section of the Chikugo River which resulted in the shortening and straightening of the river 
course. Because of these shortcuts and the building of continuous embankments the velocity became faster. Whereas in 1925-32 it took 9.2 hours from Hida to Kurume, in $1942-52$ the time was reduced to only 4.8 hours. Owing to this increased velocity of flood current, the river bed between the river mouth and Ryochi$\mathrm{ku}$ Bridge, which is situated $45 \mathrm{~km}$ upstream from the river mouth, was lowered by $43 \mathrm{~cm}$ (from 1923 to 1953 and 1961). This lowering was caused not only by the man-made construction which affected the velocity of the river, but also by the excavation of sand and gravel in the river bed. Thus, in the middle reaches of the Chikugo River, erosion is more important than deposition; this is due to the nature of the physical features and changes brought in by human skill.

In this area inundation is small and deposition is limited. But the topography is inconvenient for water use. Moats which are well developed in the lower reaches of the Chikugo River are counter measures to this condition of water shortage. Flood types similar to the Chikugo River occur in the Shonai and Yamagata Intermontane Depression (the Mogami River) and in the Niigata Plain (the Agano River), (Tada et al. 1956, Oya 1973b, 1977).

\section{Overflowing type and concentration type: Vientiane Plain in the Mekong River}

A third type, which is rather rare, can be designed by combining the two main types. For example, the Kano River Plain is divided into two parts: the Takata Plain in the upper course is characterized by the overflow type, and the lower part by the concentration type.

The Mekong River: the Vientiane Plain in the Mekong River of Indo-China presents the combination of overflow and concentration types of flooding. Under the Pa Mong Dam Project, the author was asked to determine the present state of flooding in the Vientiane Plain, for which a geomorphological survey map of the Mekong River Basin was prepared (Fig. 6). It was observed that the alluvial fan has very limited area in this region owing to the flatness of the topography and weathering of the rocks to laterite by chemical processes. On the other hand, there are big natural levees along the river courses, and back-marshes generally occupy the area between two natural levees or between a natural levee and a terrace.

The geomorphological survey map of the Mekong River Basin helped the author to estimate the maximum area under water in periods of exceptional flooding such as that of 684.7 $\mathrm{km}^{2}$. The total area under water during the 1966 flood was $499.5 \mathrm{~km}^{2}$ which proved that the 1966 flooding was of the largest magnitude during the Holocene Age. The overflow type was seen in the upper part of the Vientiane Plain, while the lower part of the plain was dominated by the concentration type. Hence, protective dikes are more useful in the upper part of the plain rather than in its lower part. The map also helped in the construction of a railway line between Nongkhai and Vientiane and in the selection of sites for stations on the terraces which avoided flood-prone areas (Oya 1967, 1980).

\section{Utilization of a Map of a Plain Where Flood Control Work Has Been Done Well}

\section{Inundation by local rainfall without bank col- lapse in the urban region}

The inundation caused by local rainfall has become remarkable in the urban area in Japan in the last few several decades. The nature and extent of such inundation can also be estimated by using geomorphological survey maps of the region which exhibit the relationship between the topography of the Neyagawa River Basin near Osaka and inundation caused by the local rainfall in July 1967. The region is bordered by the Ikoma Mountains in the east, Uemachi Terrace in the west, the Yamato River in the south, and the Yodo River in the north. The former river has a big natural levee and the latter has a small one. The nearer to the rivers the land is, the higher it becomes. The drainage-basin of the Neyagawa River is surrounded by these hilly areas, so drainage is difficult.

The southern part of the drainage-basin of the Neyagawa River has been formed by the deposition of the Yamato River. Due to great quantities of gravel, sand, and other deposits from the Yamato River, the southern part of the 
region is slightly higher with steeper slopes than its northern counterpart. The entire area is divided by many natural levees indicating the former courses of the Yamato River, and its tributaries. Also, there are numerous backmarshes surrounded by natural levees which accelerate local inundation. The northern part of the drainage-basin of the Neyagawa River has been formed by the small volume of deposition transported by the Yodo River. The height of the area is lower, and the slope is more gentle, so inundation happens easily. Urbanization is very fast while the preparation of sewerage is insufficient, causing obstruction to natural drainage. Fortunately, the natural levees are still quite safe in times of flooding (Oya and Nakamura 1969).

\section{Estimation of a map of an area affected by integrated flood control}

In Japan urbanization has advanced extremely rapid during recent years. Urbanization not only causes obstruction to natural drainage but augments the rate of run off and velocity. As a counter measure to such a situa- tion it is necessary to introduce the concept of comprehensive flood control. The concept was first initiated in the U.S.A. In the U.S.A. and Canada, the study of flood-plain management by G.F. White, and his dedicated group of researchers gained national attention as they pursued the problems of increased urban occupancy of the flood plain (Dougal 1969).

The concept puts emphasis on non-structural methods such as building codes, flood insurance, etc. In this case the zoning on flood protection has been done by utilizing not the geomorphological map but a map showing the state of flooding, especialy the maximum flood in the area. The above mentioned method is used when the flood plain has been formed by erosion and its relief is very small.

The first example of non-structural flood control was implemented by the city of Nagoya. After the Typhoon Ise-Bay in 1959, the city authorities of Nagoya and the Ministry of Construction took measures for comprehensive flood prevention. On the basis of the flood features and damages, the southern part of the city was divided into five zones and building

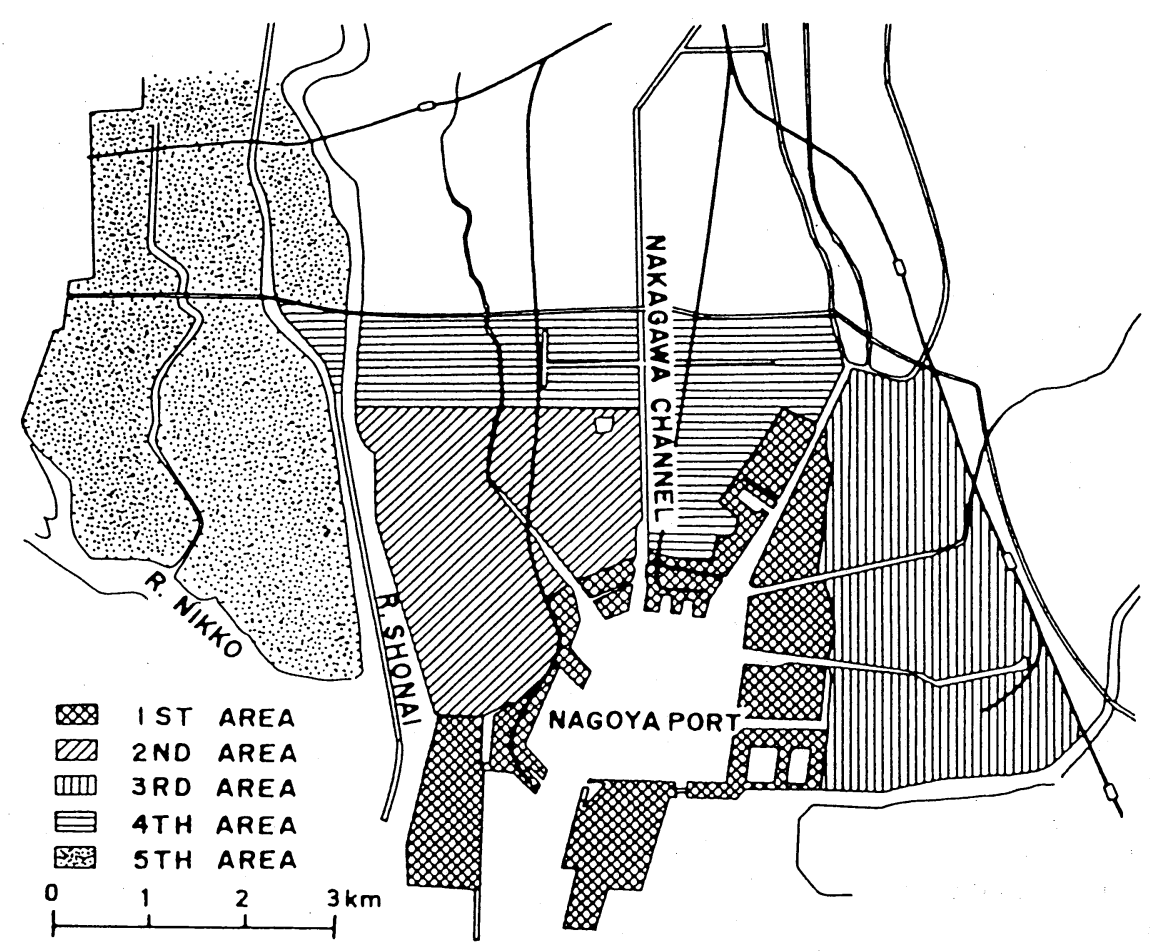

Figure 7.1. Construction zoning to meet flood danger (Oya 1970). 


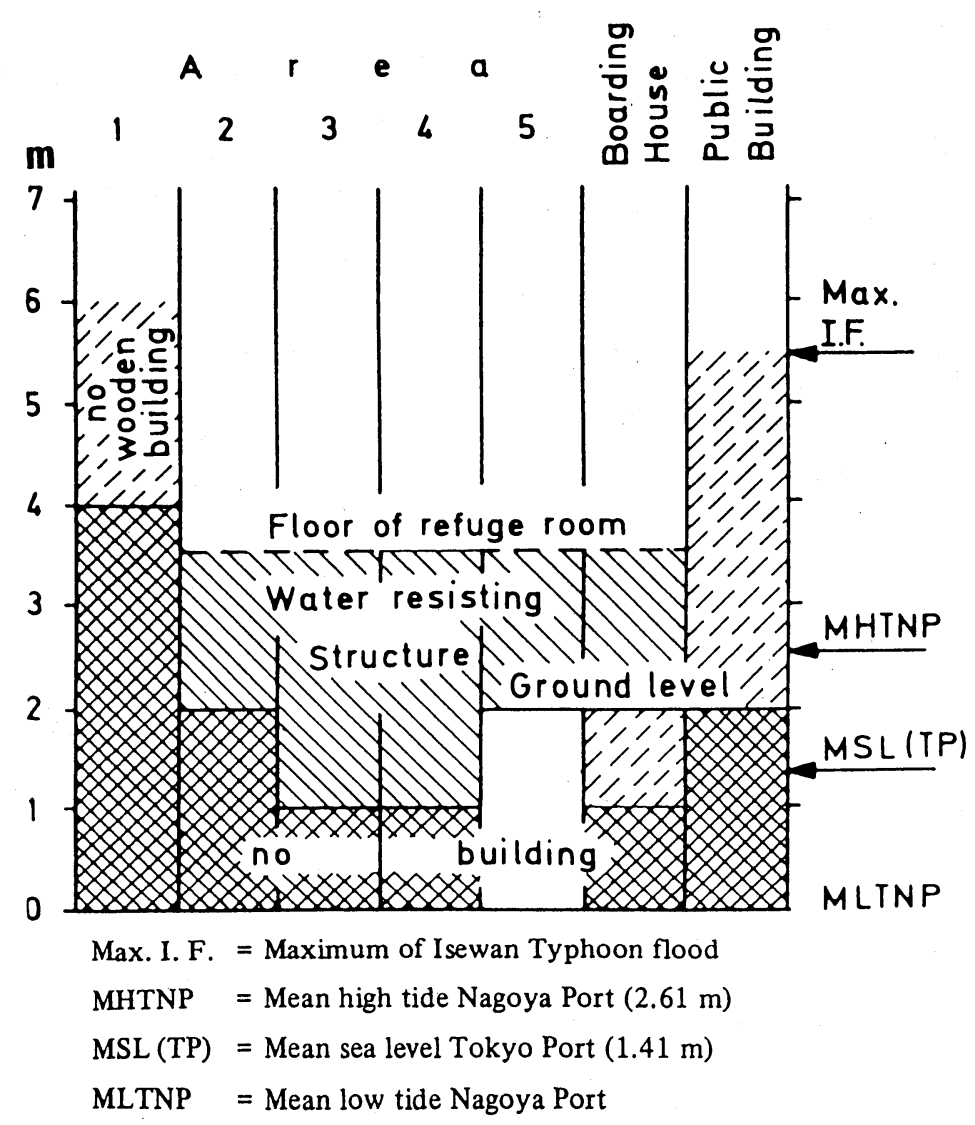

Figure 7.2. Regulation of architecture (Oya 1970).

regulations were issued for each zone (Fig. 7). The first area, covering artificially filled land around the Port of Nagoya, was asked to construct all future buildings in concrete. The second area, where the reclaimed land is surrounded by artificially filled land on the sea-side and by rivers in the west and east, was allowed to have included refuge room of at least $3.5 \mathrm{~m}$ above ground level in the buildings. The third area consisting of reclaimed land for urban purposes was given similar instructions as the second area. The fourth area of the older reclaimed land and the fifth area of reclaimed land utilized for agriculture were asked to construct buildings with water resistant structures up to $3.5 \mathrm{~m}$ high.

Utilization of the map in the integrated flood control system prepared by the Ministry of Construction

At present, the Ministry of Construction has prepared the following comprehensive flood control plan on the rivers in the cities. The drainage river basin is divided into three parts: a water holding area, a water retarding area, and a lowland.

A water holding area: a mountainous or hilly area in the upper reaches. In this area, rainwater infiltrates through the ground and is held as soil-and ground-water temporarily.

A water retarding area: a valley plain or intermountane depression in the upper reaches. In this area, water flow is retarded.

In the above mentioned two areas, construction of a regulation pond or pillottes architecture would be highly recommended.

A lowland area: a flood plain in the lower reaches. The area becomes inundated with overflowing water from the river. The inundation of the area is protected by the embankments.

The above mentioned classification has been done utilizing the geomorphological survey 
map which shows classification of flood stricken areas first, and the land use map second.

\section{Utilization of a Geomorphological Survey Map of a River Basin Showing Classific- ation of Flood Stricken Areas for Estima- tion of the Area affected by Soil Lique- faction in an Earthquake}

\section{Soil liquefaction}

Earthquakes cause large scale damage through faulting, cracks, upheaval, subsidence, dislocation, landslide, soil liquefaction accompanied with spouting water, sand or mud. Particularly the effect of soil liquefaction is dramatic and drastic when it occurs in the central area of a city, and can result in large scale collapse of buildings. This type of damage occurred to various buildings in the city of Niigata at the time of the Niigata Earthquake in 1964. Akagiri and Wakamatsu (1991) conducted research on site conditions of liquefaction in four typical plains of Japan, i.e., the Nobi Plain, the Kanto Plain, the Shonai Plain and the Fukui Plain. Figure 8 shows the distribution of liquefied sites in the Shonai Plain (Oya et al. 1982).

You can find close relationships between geomorphology and liquefied sites in the plain.

(1) The characteristics of soil liquefaction are influenced by geomorphological condi- tions of the area. For example, in the case of a relatively large plain composed of various geomorphological units such as the Nobi Plain or the Kanto Plain, the site of liquefaction varies according to the location of the epicenter of the earthquake; that is whether the epicenter lies inland or in the sea, or in the lowland or the mountain district.

(2) In each alluvial plain, a close relationship may be seen between various geomorphological units and the occurrence of soil liquefaction. Thus the prediction of soil liquefaction becomes possible in every geomorphological unit (Table 3).

(3) The probability of liquefaction in every unit mentioned above varies according to the geomorphological type of the plain: (a) the valley bottom plain has a low probability of liquefaction except of the area close to the epicenter of the earthquake; (b) the alluvial fan has a probability of liquefaction at the apex and on the skirts of the fan lying near the epicenter; (c) the natural levee has a high probability of liquefaction; (d) the back-marsh shows low probability of liquefaction except the marginal part of a natural levee and the former river courses; and (e) the delta, reclaimed land and artificially filled fields have a high probability of liquefaction.

The above mentioned relationships were seen frequently, for example, in the Nihonkai Chubu Earthquake (1983, M=7.7), the Chibaken Toho

Table 3 Relationships between geomorphological element and possibility of Liquefaction subject to seismic ground motion of the J.M.A. initensity 5

\begin{tabular}{|c|c|}
\hline Geomorphological elements & Possibility of Liquefaction subject to seismic ground motion \\
\hline Terrace & None \\
\hline Valley Plain & Low \\
\hline Fan & $\begin{array}{l}\text { Low in general, but exists to some degree in the spring-zone lying along the } \\
\text { lower edge of fan }\end{array}$ \\
\hline Natural levee & Exists to some degree at the marginal part of the natural levee \\
\hline Back-marsh & Low in general, but exists to some degree \\
\hline Delta & Low in general \\
\hline Former river course & High \\
\hline Sand spits & Low \\
\hline Sand dune & Low in general, but high on the inland skirts of the sand dune zone \\
\hline Lowland between sand dune & Exists and high around the springs especially \\
\hline Reclaimed land & Low \\
\hline $\begin{array}{l}\text { Artificially filled up field in } \\
\text { shallow sea }\end{array}$ & High \\
\hline
\end{tabular}


Geomorphological Land Classification

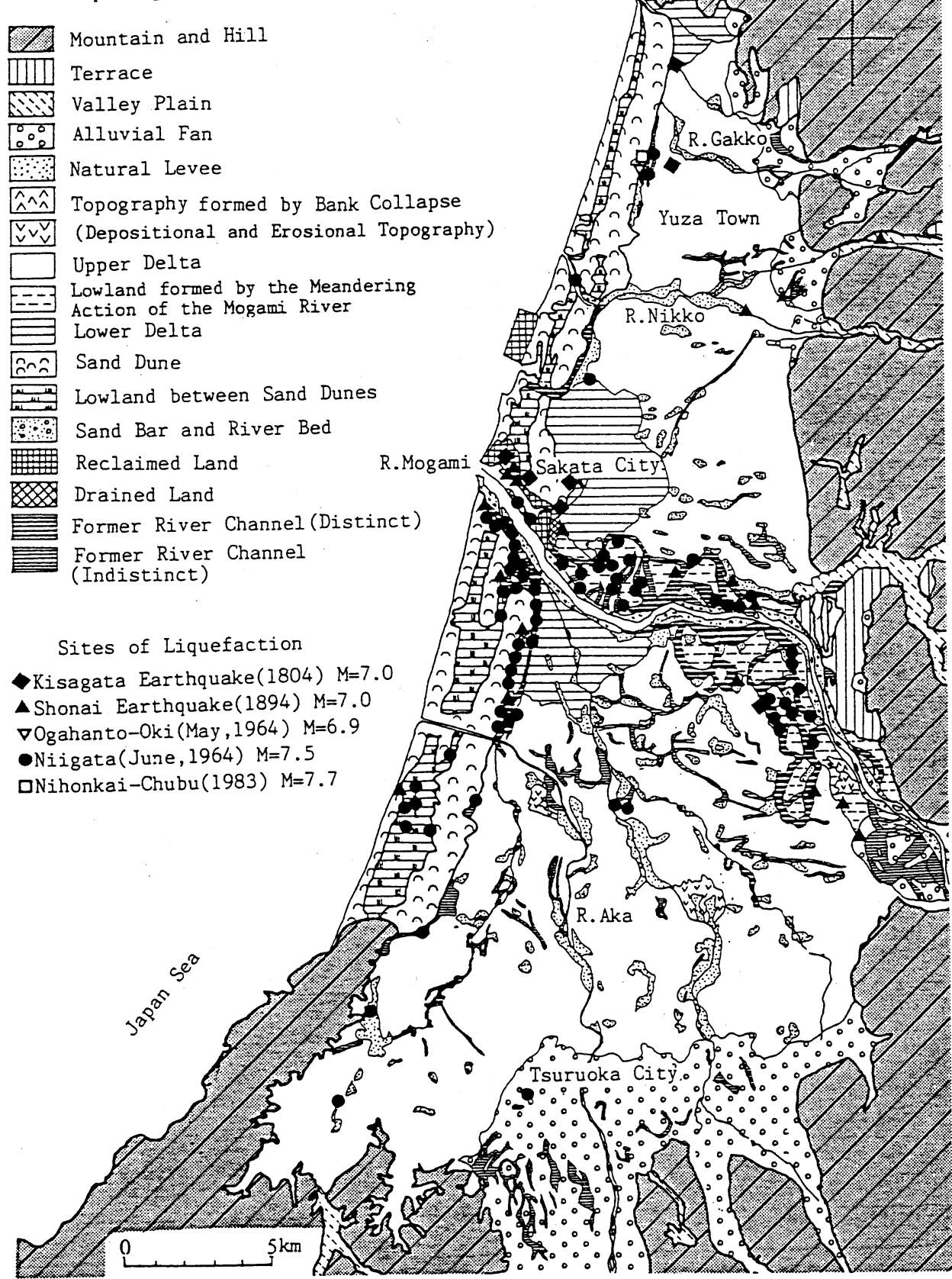

Figure 8. Geomorphological land classification map and liquefied sites in Shonai Plain (Oya et al 1982).

Oki Earthquake (1987, $\mathrm{M}=6.7)$, and the Hyogo Prefecture Nanbu Earthquake (1995, $\mathrm{M}=7.2)$. The Hyogo Prefecture Nanbu Earthquake,
1995: the Great Hanshin Earthquake

On January 17,1995 , a strong earthquake of magnitude 7.2, the Hyogo Prefecture Nanbu Earthquake, occurred in Kobe City and its vicinity. As a result of the earthquake about 6,300 people died. The heavy damage that occurred was due to the location of the epicenter-directly under the ground of Kobe City and its vicin- 


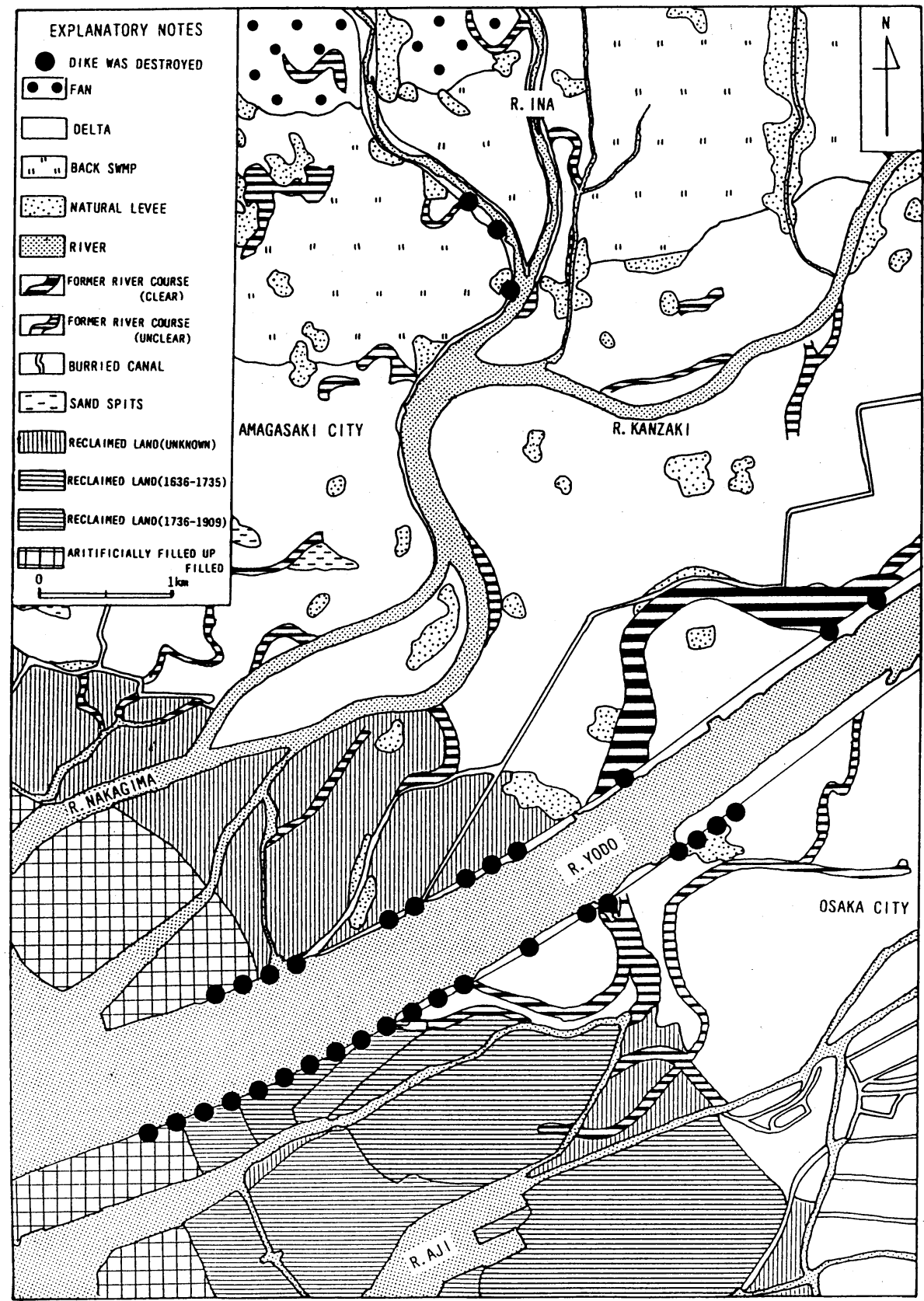

Figure 9. Geomorphological survey map of the Yodo River Basin showing classification of flood stricken areas and hazard by earthquake in 1995 (Oya and Kubo 1993; modified).

ity. A remarkable movement of the fault line was seen in the northern part of Awajishima Island. But a clear fault was not seen in the city of Kobe. The embankments in the lower reaches of the Yodo River and the Ina River were collapsed in many places because of this earthquake. The damage was especially great at the crossing point between the present river courses and the former river courses (Fig. 9), (Oya and Kubo 1993; modified in 1995).

There was a close relationship between the damage and geomorphology, with the greatest 
damage found along the former river courses, in artificially filled fields, and at the foot of the fluvial fan.

\section{Utilization of a Geomorphological Survey Map Showing Classification of Flood Stricken Areas for the Selection of a Pro- posed Bridge Site: Brahmaputra-Jamuna River in Bangladesh}

Directly after the independence of Bangladesh, the government of Japan was requested to research the possibility of constructing a bridge across the Brahamaputra-Jamuna River. In the construction of a bridge across a river, the most important thing to be considered is the shifting of the river course and changes of the banklines of the river. The shift from the Old Brahmaputra River to the present Brahmarutra-Jamuna River occurred in the latter half of the 18th century. It is the fear of technical officials who are in charge of the management of the river in Bangladesh that the river may shift after the construction of the bridge. The government of Japan was requested to fix the whole river course of the Brahmarutra-Jamuna River. This is, however, impossible for financial reasons because the river is both too long and too wide. Bahadrabad, Gabargaon, Sirajganj and Nagarbari (Aricha) were selected as proposed bridge sites. The author was requested to select the most stable and suitable site among the four for the bridge based on applied geomorphological research.

The main causes of the shifting of the river are remarkable crustal movements, deposition of sand, variation in discharge, and a bank completely consisting of sand. To make sure of the stability of the river at the four proposed bridge sites, the author (1) investigated the change of banklines and the location of thalweges and (2) prepared a geomorphological map of the Brahmaputra-Jamuna River Basin $(1: 50,000)$ and a geomorphological map of the BrahmaputraJamuna River and Ganges River Plain (1: $1,000,000)$.

(1) The author researched the change of banklines and the location of the thalweg from 1830 to the present. At the Bahadrabad site, due to the rising of the river bed, the expanding of river width and braiding of river channels are continuing (Fig. 10).

Nagarbari (Aricha) is located at the confluence between the Ganges and BrahmaputraJamuna Rivers. The peak of the flood discharge of the Ganges generally occurs about one month later than that of the BrahmaputraJamuna River. Due to the back-water of the Ganges, bank erosion, change of river course, and shifting of the thalweg at Nagarbari (Aricha) are the greatest among the four proposed bridge sites. The change is smaller at the Gabargaon and Sirajganj sites.

(2) The geomorphological map of the Brahmaputra-Jamuna River has been prepared by utilizing the mosaic of aerial photographs which were taken in 1974 by the Japanese Reconnaissance Team as a base map. The author has prepared the map by the use of the photographs and conducted field observation by boat and jeep.

The rivers, bordering with India to Sirajganj and having a braided flow, are similar to rivers in an alluvial fan. There are natural levees, back-marshes, and abandoned river courses in the alluvial fan around the Bahadrabad and Gabargaon. The author estimated that the natural levees and back-marshes were originally formed by the Tista, Jamuna, and Jhinai Rivers, and that the alluvial fan, formed by the Brahmaputra-Jamuna River, had partly covered the natural levees, back-marshes, and former river courses after the shifting of the BrahmaputraJamuna River. In the future, the area of the natural levees, back-marshes, and abandoned river courses in the fan will be buried by the shifting of the course.

Sirajganj and Balktia, which are located across the river from Sirajganj, are situated on the old alluvial plain which was formed by the Tista, Jamuna, and Jhinai River, more than 180 years ago. The old alluvial plain is separated from the present alluvial plain by a cliff, whose relative height is about $3 \mathrm{~m}$. The width of the new plain between the old plain is $7 \mathrm{~km}$ at its narrowest point. The author believes that firstly, the narrows have been formed by upheaval, partly because the cliff is the highest at Balktia and gradually decreases in height to the north and south; secondly, the abandoned river 


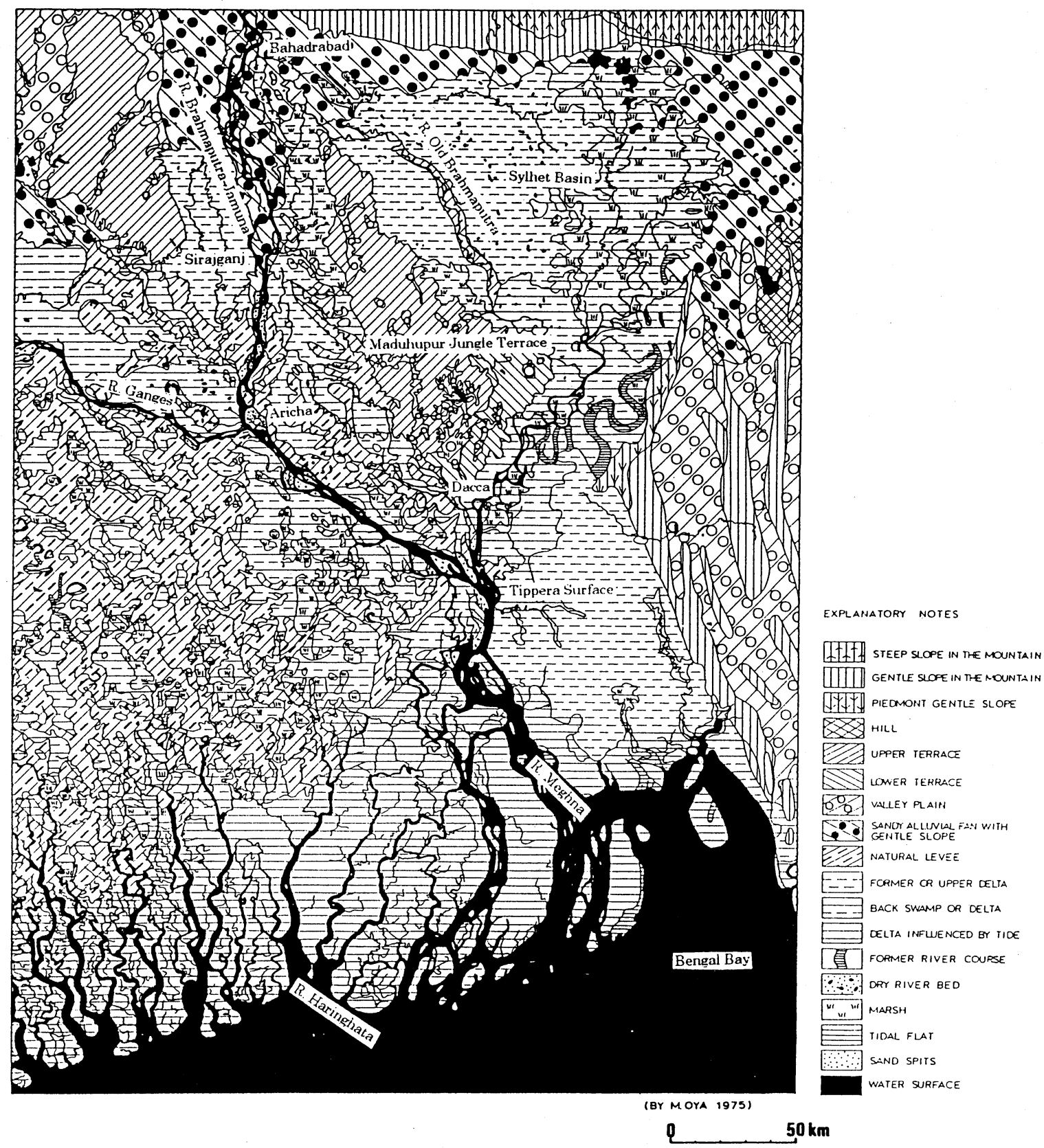

Figure 10. Geomorphologic map of the R. Brahmaputra-Jamuna and R. Ganges Plain (Oya 1977b).

courses were concentrated in the upper part of the narrows and bifurcated in the lower part of the narrows; and thirdly, the small terraced surface, its relative height being $1.5 \mathrm{~m}$ at Balktia, was formed by the Brahmaputra-Jamuna River. Moreover, the area has experienced upheaval of about $1.5 \mathrm{~m}$ during the last 180 years.
The above mentioned facts show that the narrows will remain for a minimum of 100 years which are the durable years of the bridge, and the river will keep its stability in the direct lower reach of the narrows (Fig. 11).

(3) The geomorphological map of the Brahmaputra-Jamuna Plain has been prepared 


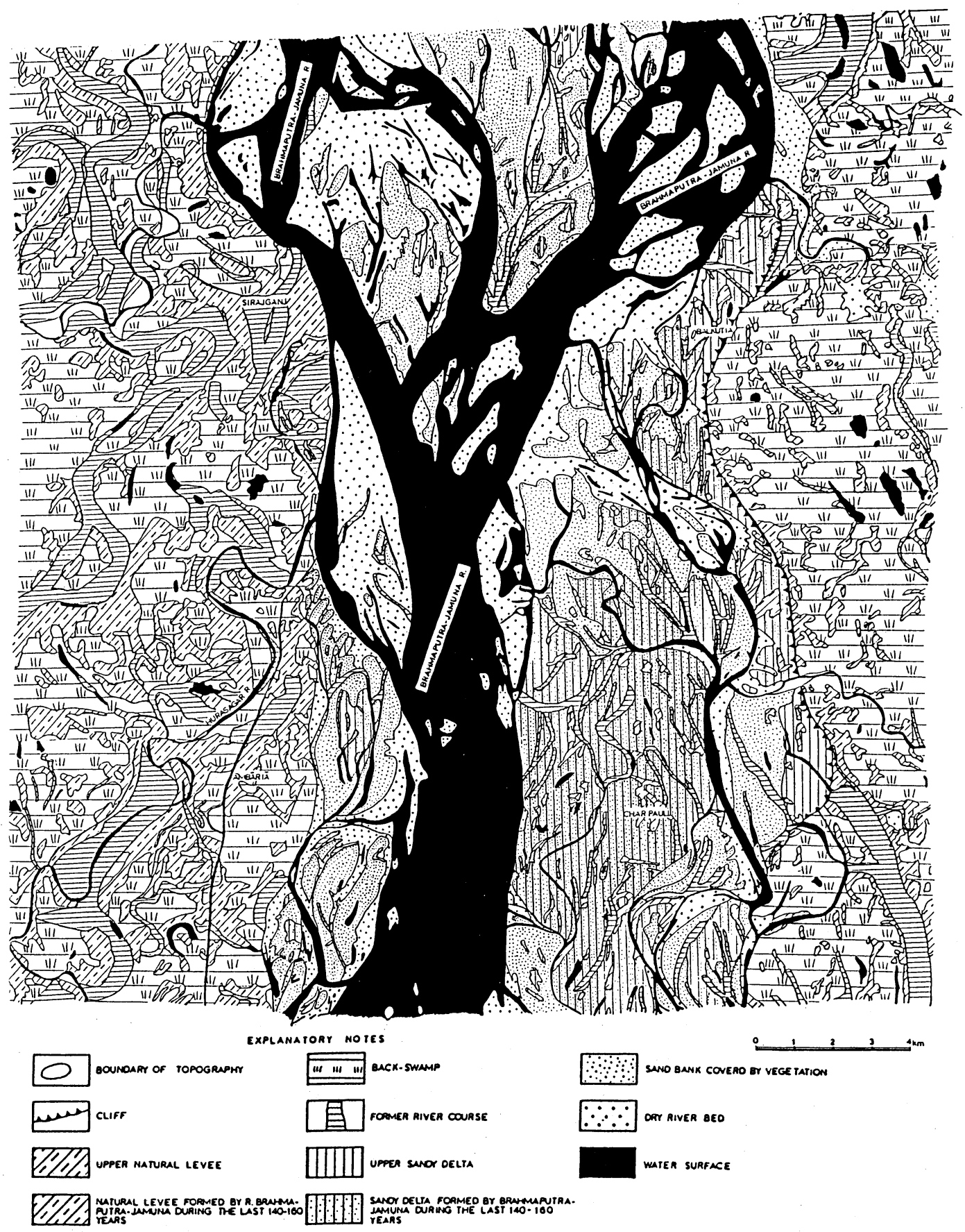

Figure 11. Geomorphological land classification map of the Brahmaputra-Jamuna River (Sirajganj and its vicinity) (Oya 1977b).

by the author by the use of the mosaic of the infra-red images of ERTS-I taken in 1972 as a base map, interpretation of the images and field observation by helicopter.

The Maduhupur Jungle Terrace, and Tippera
Surface were formed by upheaval, and the Sylhet Basin, Brahmaputra-Jamuna Valley and Ganges Plain were formed by tectonic subsidence. The alluvial plains consist of an alluvial fan formed by the Brahmaputra-Jamuna and 
the old Brahmaputra River.

The distribution of the geomorphological units is determined by the two directions of the echelon fault lines or by the lineament which originated from the fault. One fault line is from the Garo-Rajmahal Gap to the Burma Trench via the Meghna River Mouth, i.e., from NW to $\mathrm{SE}$. The other is from the Sylhet Basin to the Swatch of No Ground via the river mouth of the Haringhata. If displacement is to occur with an earthquake, the guide bank would be lowered unequally and the bridge would consequently be destroyed. According to the research, the author found that the Bahadrabad and Gabargaon are located near the fault line or lineament, but he could not recognize any remarkable fault line or lineament at Sirajganj.

Based on the above mentioned facts, the author concluded that the Sirajganj site is the most suitable place of the four proposed sites for construction of the bridge.

\section{Conclusion}

The Geomorphological Survey Map Showing Flood Stricken Areas is an essential tool in the hands of geographers and geomorphologists to identify flood stricken areas and landform types in plains. Its use is becoming popular in not only estimating the magnitude of past floods but also in predicting future trends as well in order to take preventive measures for minimizing the flood's severity and resulting damage.

We can estimate not only the features of flooding in each geomorphological unit in the plain, i.e., fan, natural levee, delta, etc., but also the flood types, i.e., overflowing, concentration and combination type based on the features of the combination of the geomorphological units.

It may give us a new outlook in city planning as we can now avoid chances of inundation by local rainfall or it may even help in the estimation of liquefaction sites caused by the earthquakes and in the selection of stable sites for the construction of bridges, etc.

In developing countries its use should be popularized and expertise should be developed to take full advantage of this new technique in planning programs.

\section{Postscript and Acknowledgment}

I started to make the Geomorphological Survey Map Showing Classification of Flood Stricken Areas around 1955 under the guidance of the late Dr. Fumio Tada who was a professor at the University of Tokyo.

I express my heartfelt thanks to the late Dr. Fumio Tada.

Since the first Geomorphological Land Classification Map Showing Flood Stricken Areas in the Nobi Plain, I prepared about 40 sheets of the map in the areas along lower reaches of main rivers, not only in Japan but also in S. E. Asia. In the research and color printing, a lot of funding was required. I have been supported by the Resources Bureau of the Science and Technology Agency, the Ministry of Construction in Japan, ECAFE (ESCAP) of the United Nations, and JICA in S. E. Asia. I want to express my profound thanks to these organizations.

I have been able to compile these maps into one atlas titled "Geomorphological Survey Maps Showing Classification of Flood Stricken Areas" which was published by Waseda University Press in 1993.

On this occasion I have been requested by Dr. Gilbert F. White, a former professor at Chicago University and Colorado State University, to compile this paper based on the atlas. I express my thanks to him for giving me the chance to write this paper. Lastly, I'd like to give my thanks to Ms. Y. Koizumi who typed the paper.

(Received Aug. 25, 1995) (Accepted Dec. 16, 1995)

\section{References}

Akagiri, T., and Wakamatsu, K. 1991. Damage of soil liquefaction caused by earthquakes and use of geomorphological maps. Bulletin of the Geographical Survey Institute 36: 53-65.

Aki, K. 1952. Suigai no Nippon (Flood damage in Japan). Tokyo: Iwanami-Shinsho.

Demek, J. 1972. Manual of detailed geomorphological mapping. Academia, Publishing House of the Czechoslovak Academy of Sciences, C.S.S.R.

Dougal, M. 1969. Flood plain management, Iowa's experience. Iowa State University Press.

Geographical Survey Institute 1947. Flooding in September, 1947, Flooding report for the Tone and Ara River. Geographical Survey Institute.

Nakano, T., and Oya, M. 1960. Relationship between geomorphology and flooding caused by the $\mathrm{Ty}$ phoon Ise-Bay. Sokuryo (Measurement) 10(6): 1-13. (J)

Oya, M. 1956. A topographical survey map of the Kiso River Basin showing classification of flood stricken areas. Appendant Map of the Resources Council 
Reference Data 46, Prime Minister's Office. (J)

Oya, M. 1967. Geomorphological study of flooding immediately down-stream from Pa Mong in the Mekong River Basin. The Committee for Co-ordination of Investigations of the Lower Mekong Basin, ECAFE (UN).

Oya, M., and Nakamura, S. 1969. Geographical study on the inundation caused by the local rainfall in the Neyagawa River near Osaka. Miscellaneous Reports of the Research Institute for Natural Resources 72 : 13-32. (JE)

Oya, M. 1970. Land use control and settlement plans in the flooded area of the city of Nagoya and its vicinity, Japan. Geoforum (Germany), 1970(4): 27-35.

Oya, M. 1972. Recent trends of landform classification studies in Japan. Geographical Sciences 17: 16.

Oya, M. 1973a. Relationship between geomorphology of the alluvial plain and inundation. Asian Profile (Hong Kong) 1(3): 479-538.

Oya, M. 1973b. Basic-form of the combination of the geomorphologic elements in the alluvial plain. Gakujutsu Kenkyuu (Academic Studies), The school of Education, Waseda University, 22: 23-43. (JE)

Oya, M. 1977a. Comparative study of the fluvial plain based on the geomorphological land classification. Geographical Review of Japan 50A: 1-31.

Oya, M. 1977b. Applied geomorphological study on the selection of the proposed bridge-Site along the Jamuna River in Bangladesh. National Geographer (India) 12(2): 101-113.

Oya, M. 1980. Multifunctional uses of geomorphological survey maps in identifying flood-stricken areas and land types. National Geographer (India) 15(2): 173-195.

Oya, M. et al. 1982. Geomorphologic land classification map of the Shonai Plain illustrating features of flooding and soil liquefaction. Sakata Construction Office,
Ministry of Construction. (JE)

Oya, M and Haruyama, S. 1987. Flooding and urbanization in the lowland of Tokyo and vicinity. Natural Disaster Science 9(2): 1-21.

Oya, M. et al. 1988. Studies on the geomorphological features of the fluvial plains in Japan focusing the distribution, geomorphological land classification and its application. Geographical Review of Japan 61 B: $35-49$.

Oya, M. 1990. Report on the activities of the Working Group on the Geomorphology of the River and Coastal Plains, International Geographical Union. Gakujutsu Kenkyuu (Academic Studies), The school of Education, Waseda University, 39: 1-18.

Oya, M. 1993. Atlas: Geomorphological survey maps showing classification of flood stricken areas. Waseda University Press. (JE)

Oya, M. and Kubo, S. 1993. Geomorphological survey map of the Yodo River showing classification of flood stricken area. Yodo River Work Office, Ministry of Construction. (JE)

Tada, F. et al. 1956. Reconnaissance topographical survey on areas subject to flood part 1. Resources Council Reference Data 46, Resources Council, Prime Minister's Office. (J)

Tada, F. et al. 1957. Reconnaissance topographical survey on areas subject to flood part 2: The relationship between topography and flood type in the Chikugo River. Material of the Resources Bureau Science and Technology Agency, 13, Resources Bureau, Science \& Technology Agency. $(\mathrm{J})$

Tada, F. and Oya, M. 1959. The flood-type and the classification of the topography. In Proceedings of I.G.U. Regional Conference in Japan 1957, 192-196.

Uchida, K. 1976. Applying the standard of the international land classification of I.G.U. to Japan. Map 14(3): 28-32. (JE) 